\title{
A Study into the Localized Corrosion of Magnesium Alloy Magnox Al-80
}

\author{
Ronald N. Clark**, James Humpage**, Robert Burrows*, Hugh Godfrey***, Mustufa Sagir****, Geraint \\ Williams** \\ ‡Corresponding author. E-mail: ronald.clark@uknnl.com.
}

*National Nuclear Laboratory, Unit 102B, Sperry Way, National Nuclear Laboratory, Stonehouse, GL10 3UT, UK

**Swansea University, Materials Research Centre, Bay Campus, Fabian Way, Crymlyn Burrows, Swansea, SA1 8EN, Wales, UK

***National Nuclear Laboratory, Workington Laboratory, Havelock Road, Derwent Howe, Workington, Cumbria, CA14 3YQ, UK

****Sellafield Limited, Hinton House, Birchwood Park Avenue, Risley, Warrington, Cheshire, WA3 6 GR, UK

j.d.humpage.869054@swansea.ac.uk

Robert.burrows@uknnl.com

Hugh.godfrey@uknnl.com

Mustufa.sagir@sellafieldsites.com

Geraint.williams@swansea.ac.uk

\section{ABSTRACT}

Magnesium (Mg) non-oxidizing alloy, known as Magnox, was historically used as a fuel cladding material for the first-generation of carbon dioxide $\left(\mathrm{CO}_{2}\right)$ gas-cooled nuclear reactors in the UK. Waste Magnox is currently stored in cooling ponds, pending final disposal. The corrosion resistance of $\mathrm{Mg}$ and its alloys is relatively poor, compared to modern cladding materials such as zirconium ( $\mathrm{Zr}$ ) alloys, so it is important to have a knowledge of the chloride concentration/pH dependence on breakdown and localized corrosion characteristics prior to waste retrievals taking place. Our results show that Magnox exhibits passivity in high $\mathrm{pH}$ solutions, with charge transfer resistance and passive film thicknesses showing an increase with immersion time. When chloride is added to the system the higher pH maintains Magnox passivity, as shown through a combination of potentiodynamic and time-lapse/post corrosion imaging experiments. Potentiodynamic polarization of Magnox reveals a -229 mV-decade linear dependence of breakdown potential with chloride ion concentration. The use of the scanning vibrating electrode technique (SVET) enabled the localized corrosion characteristics to be followed. At high $\mathrm{pH}$ where Magnox is passive, at low chloride concentrations, the anodes which form predominantly couple to the visually intact surface in the vicinity of the anode. The high $\mathrm{pH}$ however means that visually intact Magnox in the vicinity of the anode is less prone to breakdown, restricting anode propagation such that they remain largely static. In high chloride concentrations the higher conductivity means that the anode and cathode can couple over greater distances and so propagation along the surface can occur at a much faster rate, with the visually intact surface acting as a distributed cathode. In addition, the chloride anion itself, when present at high concentration will play a role in rapid passive film dissolution, enabling rapid anode propagation.

KEY WORDS: Magnesium, Magnox, Chloride Ion Concentration, Temperature, pH, Potentiodynamic, Scanning Vibrating Electrode Technique, Electrochemical Impedance Spectroscopy, X-ray diffraction, SEM, Focused ion beam 


\section{INTRODUCTION}

A key aspect to the safe clean-up and decommissioning of the Magnox Swarf Storage Silo (MSSS), located at Sellafield in the UK, is the retrieval, sorting, and repackaging of a large quantity of legacy nuclear waste currently stored within the silo. The bulk of the legacy waste is a magnesium (Mg) non-oxidizing alloy, more commonly known as Magnox, which was used to clad uranium (U) metal fuel from the first generation of UK carbon dioxide $\left(\mathrm{CO}_{2}\right)$ gas-cooled nuclear reactors. These reactors were originally constructed in the 1950s, and the last ceased its operations in 2015. Mg was used as a cladding material in these reactors for a number of reasons, such as: a low neutron cross-section (transparent to neutrons), resistance to oxidization in $\mathrm{CO}_{2}$, chemical compatibility with $\mathrm{U}$ and sufficient ductility to withstand the stresses caused by the fuel during irradiation. These are in addition to the ease of machining and welding. The major drawback of using Mg for cladding fuel is its poor corrosion resistance during aqueous storage at the end of useful service life in reactor. In 2019 the UK completed defueling of all Magnox-type reactors, and in line with the UK Magnox operating plan all spent fuel from these reactors is to be reprocessed by the end of $2020 . .^{1,2}$ Before the fuel can be reprocessed, the Magnox cladding is stripped from the spent fuel. Currently the waste cladding, which is known as Magnox swarf, is encapsulated in cement. From the mid-1960s to around the late 1980s however the swarf was stored under water in the Magnox Swarf Storage Silo (MSSS). To decommission MSSS where Magnox and its corrosion products are stored, the waste will need to be retrieved and repackaged into modern duplex stainless steel storage containers, and then interim stored until a UK geological disposal facility (GDF) becomes available. The expected corrosion rate over the interim storage period, and therefore waste expansion due to the formation of voluminous corrosion products within the containers will need to be considered before the containers are filled, so that the waste can be stored safely. There is an opportunity to optimise the waste fill levels, such that the number of containers required may be reduced. To do so however, further information on the future corrosion rate of Magnox is required.

$\mathrm{Mg}$ is thermodynamically very active, it oxidizes rapidly, spontaneously forming a thin $\mathrm{Mg}$ oxide (MgO) film in dry oxygenated environments. ${ }^{3}$ Based on thermodynamics, the oxidised states of $\mathrm{Mg}\left(\mathrm{Mg}^{2+}, \mathrm{MgO}\right.$, and magnesium hydroxide $\left.\left(\mathrm{Mg}(\mathrm{OH})_{2}\right)\right)$ are $\mathrm{more}$ stable than that of $\mathrm{Mg}$ metal, and of these $\mathrm{Mg}(\mathrm{OH})_{2}$ is most thermodynamically favoured. ${ }^{3}$ For pure $\mathrm{Mg}$ exposed to an aqueous environment, the corrosion film is composed of a dual structure, consisting of the thin partially protective $\mathrm{MgO}$ film and a thicker, porous, $\mathrm{Mg}(\mathrm{OH})_{2}$ outer film. As described by Song, ${ }^{3}$ film formation on $\mathrm{Mg}$ is achieved by two processes. In the first, $\mathrm{Mg}$ metal reacts instantaneously with $\mathrm{H}_{2} \mathrm{O}$ once immersed, forming $\mathrm{Mg}(\mathrm{OH})_{2}$, and in the second, $\mathrm{MgO}$ is dissolved, which, due to the low solubility of $\mathrm{Mg}(\mathrm{OH})_{2}$ in solution, then precipitates back on the surface as an incomplete porous film of $\mathrm{Mg}(\mathrm{OH})_{2}$. This precipitated outer $\mathrm{Mg}(\mathrm{OH})_{2}$ film is not protective. If elements such as chloride $\left(\mathrm{Cl}^{-}\right)$or fluoride $\left(\mathrm{F}^{-}\right)$, are present in the aqueous environment, these can be incorporated into the outer $\mathrm{Mg}(\mathrm{OH})_{2}$ film, which can be protective (e.g. $\left.\mathrm{F}^{-}\right)$, or detrimental (e.g. $\left.\mathrm{Cl}^{-}\right){ }^{3,4}$ If the surface is exposed to sulfur dioxide $\left(\mathrm{SO}_{2}\right)$ or $\mathrm{CO}_{2}$ environments, sulfur $(\mathrm{S})$ or carbon (C) can also react with $\mathrm{Mg}(\mathrm{OH})_{2}$, thereby forming magnesium sulfates $\left(\mathrm{MgSO}_{4}\right)$ or magnesium carbonates $\left(\mathrm{MgCO}_{3}\right)$ on the surface. ${ }^{3}$ To simplify the present investigation, reactor-formed films are not considered

in this work. ${ }^{i}$ For further information on as-received films, moist-air films and reactor-gas formed films on Magnox the reader is referred to the works of Allen ${ }^{5}$, Hallam et al., ${ }^{6}$ and Bradford et al. ${ }^{7}$ Characterization of Magnox surface films following exposure to aqueous environments has been performed using spectroscopic and nuclear convolution methods by Majchrowski ${ }^{8}$ and Jarjis. ${ }^{9}$ Historical discussion can be found in Case and Hinton ${ }^{10}$ and Friskney et al. ${ }^{11}$ who summarised the effects of $\mathrm{F}^{-}$and $\mathrm{NaOH}$ on Magnox corrosion in relation to aqueous environments. Other authors have used electrochemical noise (EN) and electrochemical impedance spectroscopy (EIS) to study the response of Magnox to high pH environments. ${ }^{12-14}$ Kirby $^{15}$ studied the effect of a combined galvanic couple with steel and crevices on the aqueous corrosion of Magnox Al-80, and

${ }^{\mathrm{i}} \mathrm{CO}_{2}$ was used as a coolant in the Magnox reactors, and real cladding has a more complex film structure than the simple form considered in this paper 
showed that when Magnox was clamped to mild steel bars - with a surface area ratio of 1:3.63 (Magnox:bar) in pH $11.7 \mathrm{NaOH}$ (200 ppm

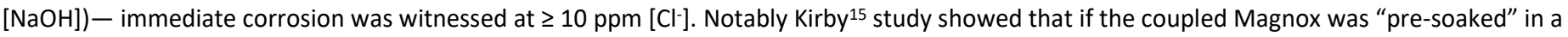
$\mathrm{NaOH}$ solution for a period of 20 days, and then dosed with $\mathrm{Cl}^{-}$, the Magnox had a reduced susceptibility to corrode which was attributed to the formation of passive film. Somewhat more recently, Laferrere et al. ${ }^{16}$ applied state-of-the-art methods to characterize the corrosion of Magnox and stainless steel. The authors used the scanning vibrating electrode technique (SVET) and time-lapse imaging (TLI) to capture propagation of corrosion on Magnox Al-80 in a high $\mathrm{Cl}^{-}(2.5 \% \mathrm{w} / \mathrm{v} \mathrm{NaCl}(\mathrm{aq}))$, neutral $\mathrm{pH}$ environment over the course of a 24 hour period. They demonstrated the use of high speed atomic force microscopy (HS-AFM) for post corrosion imaging of Magnox corrosion filaments, and how it could be used to monitor in-situ corrosion processes on stainless steels.

Past work has shown that SVET and TLI are effective methods for tracking the initiation and propagation of corrosion on Magnox in neutral $\mathrm{pH}$, high $\mathrm{Cl}^{-}$environments. Others have studied the effect of $\mathrm{NaOH}$ on Magnox using EIS, but only for short periods of up to one day. Consequently, what is needed is information on the response to conditions of high $\mathrm{pH}$ using $\mathrm{NaOH}$, combined with little or no $\mathrm{Cl}^{-}$, for extended time periods. In this work the corrosion of Magnox Al-80ii has been studied using a combination of methods, including: X-ray diffraction (XRD), cross sectioning, potentiodynamic polarization, EIS, TLI, and SVET. XRD and cross sectioning were used to characterise the effect of NaOH on the Magnox passive film for periods of up to 1 year. Cross sectioning was performed using focussed ion beam (FIB) combined with scanning electron microscopy (SEM), which was considered advantageous over conventional metallographic sectioning as mechanical disruption of thin or friable films is minimised. Potentiodynamic polarisation was used to build an understanding of the effect of various parameters ( $\mathrm{Cl}$, temperature, $\mathrm{pH}$ ) on $\mathrm{Magnox}$ breakdown. EIS was performed for periods of up to a month to gather information on passive film formation in $\mathrm{NaOH}$ without $\mathrm{Cl}^{-}$with respect to time. TLI combined with post corrosion imaging allowed qualitative information to be obtained on corrosion in high $\mathrm{pH}$, low $\mathrm{Cl}^{-}$environments.

The main aims of this investigation were twofold: (i) to characterize the effect of $\mathrm{NaOH}$ on Magnox passivity, (ii) the dependence on $\mathrm{Cl}^{-}$ concentration/pH on Magnox film breakdown, and in particular to contrast the localized corrosion characteristics in very high, and more modest $\mathrm{Cl}^{-}$ environments (the latter in conditions which could be considered more akin to storage). By relating the Magnox swarf waste evolution to this, and other relevant fundamental work on $\mathrm{Mg}$ corrosion, will bring the potential to make underpinned predictions about the reaction rates of the waste during retrievals and in subsequent interim storage.

\section{EXPERIMENTAL}

\subsection{Materials}

Magnox Al-80 sample material (Magnesium Elektron) was supplied as a $27 \mathrm{~mm}$ diameter bar and cut into specimens of the desired size by linear precision saw. To prepare working electrodes for d.c. and a.c. electrochemistry, an electrical drill was used to create a small 1 mm diameter hole in the back of the specimen, and to this a small bolt was secured. A wire was then wrapped around the bolt, the connection encapsulated in conductive Ag epoxy, and then allowed to cure at room temperature. Specimens were then mounted in a cold set epoxy and allowed to cure for a period of 24 hours. A mechanical grinding wheel was used to prepare specimens using SiC paper. Following grinding, specimen surfaces were cleaned using ethanol to remove any residual debris. Specimens were reused following completion of potentiodynamic polarization experiments, as generally only superficial pitting was present (reused specimens were reground). The typical composition of Magnox Al-80 is given in Table 1 , and a summary of the different characterization techniques and experiments undertaken as part of this paper is shown in Table 2.

ii Other variants of Magnox were produced, such as Magnox Zr-55, which was used for fuel cladding splitter blades 


\subsection{Characterization}

X-ray diffraction (XRD) spectra were obtained using a Phillips X'pert Pro diffractometer with a Cu K- $\alpha$ source. Due to the small film thicknesses expected for the corrosion surface film, analysis was conducted over a 24 hour period. The scan range was $20-90^{\circ}(2 \theta)$, and a $0.02^{\circ}$ step size was used for a total of 3500 datapoints. The dwell time was $25 \mathrm{~s}$ per step. A specimen which was not immersed was also analyzed as a control, with the same scan range and step size, but shorter dwell time ( $2 \mathrm{~s})$. This was pickled prior to analysis by immersing the specimen in a solution of $2 \% \mathrm{w} / \mathrm{v}$ citric acid (aq) at $60^{\circ} \mathrm{C}$ for a period of 2 minutes. Phase identification was performed with proprietary software with standard libraries.

Cross sectioning of specimens was undertaken using a FEI Helios NanoLab 600i Dual Beam focused ion beam scanning electron microscope (FIB-SEM). Specimens were aligned and tilted to $52^{\circ}$ so that the incident ion beam was perpendicular to the surface. A layer of platinum (Pt) was deposited to protect the surface during the milling process ( $20 \times 3 \times 0.5 \mu \mathrm{m})$ at $30 \mathrm{keV}, 0.46 \mathrm{pA}$. A trench ( $60 \times 40 \times 4 \mu \mathrm{m}(\mathrm{w} \times \mathrm{I}$ $\mathrm{xd}$ )) was then milled across the protective layer using a standard cross section cut at $30 \mathrm{keV}, 6.5 \mathrm{nA}$ in the multiscan mode until no material was visible in the trench from the oblique SEM beam angle. Following this, cleaning cross sections at $30 \mathrm{keV}, 2.9 \mathrm{nA}$ and then $30 \mathrm{keV}, 0.9 \mathrm{nA}$ were applied closer to the protective layer to create a smooth front face of the trench for observation of the $\mathrm{MgO} / \mathrm{Mg}(\mathrm{OH})_{2}$ films. $\mathrm{Cross}$ sectioned specimens were then imaged with a Zeiss Sigma VP field emission gun SEM (FEG-SEM) using secondary electron (SE2) or InLens detectors, with an acceleration voltage between 10 and $20 \mathrm{keV}$. The cross sectioned specimens were imaged at an angle of $45^{\circ}$ relative to the surface to allow the sectioned face to be examined. Film thicknesses were calculated using ImageJ software, where the length was calibrated to the number of pixels from the scale bars in the SEM image. High magnification images of the passive film beneath the protective Pt layer were used to measure the distance normal to the surface between the $\mathrm{Mg}$ metal and the outermost layer of the film $\left(\mathrm{Mg}(\mathrm{OH})_{2}\right)$. Film thicknesses were measured in three separate locations, chosen to be broadly representative of the film variation. The thicknesses were then averaged and adjusted by a factor of 1.414 $\left(1 / \operatorname{Sin} 45^{\circ}\right)$ to account for the oblique imaging angle. Specimens were prepared to a P1200 surface finish. Pickling was undertaken on specimens used for film thickness measurement (the FIB-SEM cross sections) i.e. prior to immersion in $\mathrm{NaOH}$. Specimens were immersed in sealed plastic bottles containing 200 ppm [NaOH] and removed at different time intervals when required for analysis. Energy-dispersive X-ray spectroscopy (EDS) analysis was conducted using the Zeiss Sigma FEG-SEM discussed above with a Magnox Al-80 metallographic cross section following exposure to 200 ppm $[\mathrm{NaOH}]$ for a period of one year.

\subsection{Electrochemical Instrumentation}

A Solartron 1280b potentiostat was used for d.c. electrochemistry measurements in three electrode cell mode. The Al-80 Magnox specimen, a saturated calomel electrode (SCE), and Pt gauze were used as working, reference and counter electrodes respectively. Magnox specimens were prepared to a P2500 surface finish. Open circuit potential (OCP) measurements were conducted over a period of 10 minutes. Potentiodynamic polarization was conducted between $-2100 \mathrm{mV}(\mathrm{SCE})$ and $1000 \mathrm{mV}$ (SCE) at a scan rate of $1 \mathrm{mV} \cdot \mathrm{s}^{-1}$ in a range of chloride ion concentrations $\left(0,10,100,1000,5000 \mathrm{ppm}\left[\mathrm{Cl}^{-}\right]\right)$as sodium chloride $(\mathrm{NaCl})$. Experiments were performed with $250 \mathrm{ml}$ of electrolyte which was aerated. For experiments where the influence of $\mathrm{pH}$ was studied, electrolytes were sparged by vigorous $\mathrm{N}_{2}$ bubbling for a period of ten minutes before the experiment. These electrolytes were covered and a slow flow of $\mathrm{N}_{2}$ was used in the head space. This practice of sparging was undertaken to minimize acidification of the basic electrolytes, caused by the reaction of $\mathrm{CO}_{2}$ from the air with the electrolyte to form carbonic acid. To vary the $\mathrm{pH}$ of the electrolytes $2 \mathrm{~mol} \cdot \mathrm{dm}^{-3}(\mathrm{aq})$ stock acid and base solutions were prepared $(\mathrm{HCl}, \mathrm{NaOH})$, and droplets of these solutions were 
added by Pasteur pipette. During the addition of these droplets the $\mathrm{pH}$ was checked using a pH probe. Experiments were conducted three timesiii, and the quoted error bar uncertainty relates to one standard deviation. A water bath was used for temperature dependence experiments. A beaker containing a thermometer, electrolyte, counter and reference electrodes were suspended within the water bath using a clamp stand. A bespoke lid was used to reduce evaporation of the electrolyte. After the electrolyte reached the desired temperature the Magnox working electrode was inserted into the electrolyte, and the experiment started. For temperature curves the SCE potential was corrected according to Equation 1:iv

$$
E(S C E)=0.242-\left[7.6 \times 10^{-4} \cdot(T-298)\right]
$$

Following the d.c. electrochemistry experiments, values for the breakdown potential $\left(E_{b}\right)$, were obtained from the potentiodynamic traces. $E_{b}$ was defined as the potential in which there is a sustained sharp increase in current density following the passive region of the curve. For curves where no passive region was present, $E_{b}$ was recorded as the same potential as $O C P / E_{c o r r}$ (i.e. spontaneous corrosion without the need for polarization). $E_{b}$ values were plotted as a function of $\mathrm{pH}$, temperature and the logarithm of the chloride concentration to determine the dependence on these factors. Analysis of the residuals obtained from statistical analysis indicated that the points were randomly above and below the fit line.

Specimens for a.c. electrochemistry were prepared to a P1200 surface finish. These were immersed in $1 \mathrm{~L}$ plastic bottles containing Pt gauze reference and Pt gauze counter electrodes, which protruded through a silicone bung which was used as a seal. The sealing of the bottles was conducted to minimize acidification of the electrolyte from the air. For these electrochemistry experiments a Gamry Interface 1000 was used. A Gamry script was created (shown in Figure 1) so that OCP and EIS experiments were performed sequentially in a loop for a set duration. Potentiostatic EIS $\left(10 \mathrm{mV}_{\mathrm{pp}}\right)$ was conducted over a frequency range of $1 \mathrm{E} 5$ to $1 \mathrm{E}-4 \mathrm{~Hz}$ with 10 points per decade and analyzed using Scribner Associates ZView software. Error bars were applied to the charge transfer resistance values, obtained from equivalent circuit fitting. Error was obtained through the same software, which represents the value of several solutions near the best fit until the goodness of fit begins to decrease.

The scanning vibrating electrode technique (SVET) was conducted using a bespoke Swansea University instrument. Details on the specific experimental parameters are given here, but for full details of the instrument operation and calibration the reader is referred to the earlier works of Williams and McMurray. ${ }^{17,18}$ Specimens were prepared to P2500 surface finish, and were masked so that a $0.67 \mathrm{~cm}^{2}$ area was exposed using PTFE tape (3M HD5490). These were immersed in $1 \mathrm{~L}$ of electrolyte, with SVET scans performed continuously, using a probe to specimen distance of $150 \mu \mathrm{m}$. The distance between datapoints was $200 \mu \mathrm{m}$.

\subsection{Time-lapse Imaging}

Time-lapse imaging (TLI) experiments were conducted using a Nikon D3500 digital SLR camera mounted on a tripod, housed within a lightbox. The camera was set to capture images at the lowest ISO, using relatively long exposure times, and as narrow an aperture as possible (nominally ISO 100, exposure 1/5", aperture f22). An AC adaptor was used to provide the camera with power, and the camera controlled using software from a computer. An 18-55 mm AF-P f/3.5-5.6G VR lens was used with the lens set to $55 \mathrm{~mm}$. Several small vials were enclosed within a sealed container ( $20 \times 15 \times 15 \mathrm{~cm})$, allowing an experimental matrix of different electrolytes to be studied at the same time over a period of 9 days. Electrolytes were prepared using micropipettes, and each vial contained $10 \mathrm{ml}$ of solution. Specimens were $\sim 5 \times 5 \times 2 \mathrm{~mm}$ and prepared to a P1200 surface finish. 10, 20, 40, 60, 80 ppm [Cl-] and 10, 40, 200 ppm [NaOH] (nominally pH 10.4, 11.0, 11.7) were used. The container was sealed by a combination of grease, $1 \mathrm{~mm}$ EPDM rubber, and compression by a clamping arrangement to minimize acidification of the electrolytes. A

\footnotetext{
${ }^{\text {iii }}$ For 10 ppm chloride results were repeated two times

${ }^{\text {iv }}$ Equation obtained from ${ }^{41}$
} 
schematic of the TLI set up is shown in Figure 2. Post corrosion imaging of specimens was performed using a Sigma $105 \mathrm{~mm} \mathrm{f} / 2.8 \mathrm{EX}$ DG HSM OS Macro lens.

\section{RESULTS AND DISCUSSION}

\subsection{Characterization}

X-ray diffraction was used to characterise the crystal structure of the surface film on the magnesium alloy following immersion in 200 ppm $[\mathrm{NaOH}]$ for a period of one year (Figure 3(i)). The dosing of storage ponds with $\mathrm{NaOH}$ to prevent corrosion in the UK is a routine practice, both for Magnox and advanced gas-cooled reactor (AGR) fuel cladding materials. ${ }^{16,19,20}$ Hence the interest in deducing if this procedure affects the surface film, compared to native air-formed films. The spectrum showed peaks for $\mathrm{Mg}$ and $\mathrm{Mg}(\mathrm{OH})_{2}$ (also known by the mineral name brucite), confirming the formation of a corrosion film. In comparison, the control specimen, pickled in citric acid, showed peaks only for Mg (Figure 3(ii)). The intensity of the $\mathrm{Mg}(\mathrm{OH})_{2}$ peaks were consistent with what would be expected of a thin film. No MgO peaks were witnessed in either spectrum, which would be expected given the relatively low intensity of the $\mathrm{Mg}(\mathrm{OH})_{2}$ peaks in the XRD spectrum for the corrosion specimen (given that the $\mathrm{Mg}(\mathrm{OH})_{2}$ film is likely to be much thicker than $\mathrm{MgO}$ film).

FIB cross sectioning, and FEG-SEM imaging allowed observation of corrosion films following specimen immersion in $200 \mathrm{ppm}$ [NaOH] for periods of 3 days, 10 weeks and 1 year. From the XRD characterization undertaken, it is known that $\mathrm{Mg}(\mathrm{OH})_{2}$ is present on the specimen after immersion for 1 year in $\mathrm{NaOH}$. Whilst this did not show the presence of $\mathrm{MgO}$, studies by other authors using high resolution analytical transmission electron microscopy (ATEM), ${ }^{21-25}$ X-ray photoelectron spectroscopy (XPS) ${ }^{26}$ and SIMS $^{27}$ methods have shown the general corrosion film structure for $\mathrm{Mg}$ alloys is composed of an inner $\mathrm{MgO}$ film, and outer film, predominantly $\mathrm{Mg}(\mathrm{OH})_{2}$ with a small quantity of $\mathrm{MgO}$ present. Figure 4(i, iii, v) shows the FIB milled trenches on specimens following immersion in $\mathrm{NaOH}$, which have been annotated in Figure $\mathbf{4}(\mathbf{i}$, ii) to show the expected relevant corrosion films. SEM energy dispersive X-ray spectroscopy (EDS) analysis of a metallographic cross section is presented in Figure $\mathbf{5}$ following one year exposure to $\mathrm{NaOH}$. From each of the low magnification images (Figure $\mathbf{4}(\mathbf{i}, \mathbf{i i}, \mathbf{v}))$ it can be observed that the surface $\mathrm{Mg}(\mathrm{OH})_{2}$ film has a high surface area and porosity. Figure 4(ii, iv, vi) show high magnification images of the cross section under the deposited Pt layer. From the techniques available to the present authors, a bilayer structure is observed (Figure 4(ii, iv, vi)), consisting of a thin bright film expected to be $\mathrm{MgO}$, and a much thicker outer $\mathrm{Mg}(\mathrm{OH})_{2}$ film which increased in thickness with exposure time. The SEM-EDS analysis undertaken indicated a small amount of $\mathrm{Al}$ in the corrosion product layers $\left(\mathrm{MgO}\right.$ and $\left.\mathrm{Mg}(\mathrm{OH})_{2}\right)$, consistent with that of other past work on Magnox Al-80. ${ }^{6}$ Similar findings have also been observed on $\mathrm{AZ}^{2} \mathrm{O}^{22}$ and $\mathrm{AZ31B}^{21}$ with high angular annular dark field (HAADF) TEM analysis. In both of these studies ${ }^{21,22}$ a thin $\mathrm{Zn}$-rich layer was found to be present at the Mg-MgO interface however, which has not been observed here. Another Mg alloy, E71721,24 showed the presence of a $\mathrm{Zn}$ rich layer, but no Al was detected in the MgO layer. It is expected that this $\mathrm{Zn}$ enrichment with $\mathrm{Al}-80$ is either not present, not easily observed because of the limitations of SEM-EDS when compared to TEM-EDS, or because of the much lower Zn content within Al-80 (0.008 wt\%), compared to $\mathrm{AZ}-80^{22}(0.43 \mathrm{wt} \%), \mathrm{AZ31B}^{21}$ (1.00 wt\%) and E71721,24 (1.18 wt\%). As to the comparison with the presence of $\mathrm{Al}$ in the $\mathrm{MgO}$ film Al-80 has a greater Al content ( $0.008 w t \%)$, when compared to E717 $(<0.001 \mathrm{wt} \%)$, which helps explain the reasons why small amounts of Al has been detected in Al-80 corrosion product films. Both time of flight secondary ion mass spectrometry (ToF-SIMS) and TEM (imaging and characterisation) have been performed on commercial-purity Mg following exposure to pure water by Seyeux et al..$^{28}$ and Taheri et al. ${ }^{29}$ respectively. Seyeux et al. found evidence of a magnesium hydride $\left(\mathrm{MgH}_{2}\right)$ within the corrosion product film, along with $\mathrm{MgO}$ and $\mathrm{Mg}(\mathrm{OH})_{2}$, though the $\mathrm{MgH}_{2}$ was expected to be present in a much smaller quantity. Taheri et al. attributed the corrosion product film to be composed of a bilayer film structure with a nano-crystalline $\mathrm{MgO}$ inner film, and $\mathrm{Mg}(\mathrm{OH})_{2}$ outer film. The bilayer film structure observed in Figure 4 is therefore broadly 
consistent with that observed by other authors on $\mathrm{Mg}$ and its alloys. To attain an indication on the increase in film thickness with time, measurements were made of the overall film thickness, and tabulated in Table 3. As can be seen in Figure 4, the film thickness varied, therefore the standard deviation of three representative measurements taken along the film are given in the table. The inner MgO film thickness was too thin to measure accurately, but thickness appeared to be $\leq 20 \mathrm{~nm}$. Unocic et al., ${ }^{21}$ using TEM, published similar findings with ultra-high purity (UHP) Mg, AZ31B and E717, showing an increase in MgO film thickness during immersion in $\mathrm{H}_{2} \mathrm{O}$ as a function of time at room temperature $(4,24,48$ hours). The results presented here however show much smaller film thicknesses than that observed by Unocic et al. ${ }^{21}$ for the UHP Mg and E717 materials, even with extended exposure times of up to a year. From the TEM study Taheri et al. ${ }^{25}$ also observed much larger film thicknesses for shorter immersion times in $\mathrm{H}_{2} \mathrm{O}$ (48 hours) on commercial purity (CP) Mg. It is expected that this may be due to the difference in the Al-80 alloy composition. The findings presented by Unocic et al. ${ }^{21}$ for the AZ31B alloy showed the presence of much thinner films when compared to UHP Mg and E717 for the same immersion time and media, and therefore one could attribute this to the difference in alloy composition. From the data in the Unocic et al. ${ }^{21}$ publication it can be seen that AZ31B contains both elevated Al and Mn levels when compared to E717 (3.03 and 0.25 compared to 0.001 and $0.007 \mathrm{wt} \%)$.

\subsection{Potentiodynamic Polarization}

Magnox Al-80 specimens were subjected to potentiodynamic polarization at different $\left[\mathrm{Cl}^{-}\right]$, temperatures and $\mathrm{pH}$ to understand their effect on Magnox passive film breakdown (Figure 5). The plots show the current density response to an applied potential (E), scanned from the cathodic to the anodic region. Thermodynamically in aqueous solution, $\mathrm{Mg}$ metal will oxidize to form $\mathrm{Mg}(\mathrm{OH})_{2} \cdot{ }^{3} \mathrm{In}$ certain environments however, e.g. high $\mathrm{pH}$, without aggressive species such as the chloride anion, there exists the possibility for passivity. ${ }^{3}$ Passivating elements (e.g. Al, Ti) ${ }^{30,31}$ can be alloyed to $\mathrm{Mg}$ to assist in passivity. If these alloys are anodically polarized, a region of passivity can exist before the breakdown potential ( $E_{b}$ ) is reached, where the current density starts to rise exponentially. ${ }^{3}$ Note that this region of passivity may not be observed at low $\mathrm{pH}$, or where there

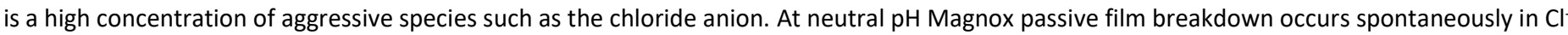
containing solutions above a critical threshold, as shown previously by Laferrere et al. ${ }^{16}$ This breakdown can be observed by following the time dependence of $E_{c o r r}$, with $E_{b}$ defined as the point in which $E_{c o r r}$ reaches a maximum value, before rapidly dropping to a local net anodic event (breakdown) as previously demonstrated on $\mathrm{Mg}$ and its alloys. ${ }^{32,33}$ At elevated $\mathrm{pH}$ however, $\mathrm{E}_{\mathrm{b}}$ can be established using more conventional means (potentiodynamic polarization), where $\mathrm{E}_{\mathrm{b}}$ is marked by an exponential rise in current density in the passive region of the anodic branch.

In the experiment where $\left[\mathrm{Cl}^{-}\right]$was varied, temperature and $\mathrm{pH}$ were fixed to $20^{\circ} \mathrm{C}$ and 11.7 respectively. From Figure $6(\mathbf{i})$ it can be

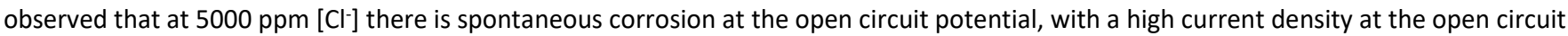
potential $\left(\mathrm{i}_{\text {corr }}\right)$, whilst at $0 \mathrm{ppm}\left[\mathrm{Cl}^{-}\right]$the metal is passive throughout the experiment. There is a decrease in current density at chloride ion concentrations lower than $5000 \mathrm{ppm}\left[\mathrm{Cl}^{-}\right]$, and it can be observed that there is a trend toward $\mathrm{E}_{\mathrm{b}}$ decreasing with increasing [Cl-]. To study the

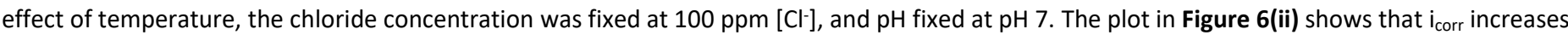
by over two orders of magnitude when the temperature is increased from 20 to $40^{\circ} \mathrm{C}$. For each of these curves at $\mathrm{pH} 7$ there was no evidence of a distinct breakdown potential, and the gradient of the curve is indicative of spontaneous corrosion at $\mathrm{E}_{\text {corr, }}$ most likely because of the lower pH. By

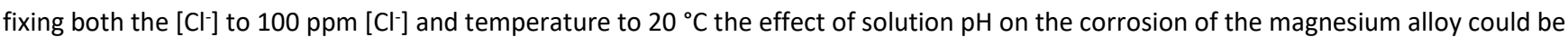
determined. The plot in Figure 6(iii) shows that the system appears to be in a passive regime at pH 11.9 and pH 13 . Similar extended passivity has been reported previously ${ }^{34}$ for high-purity $\mathrm{Mg}$ (99.96\%) exposed to $\left.1 \mathrm{~N} \mathrm{NaOH} \mathrm{(} \sim \mathrm{pH} 14\right)$ without $\mathrm{Cl}^{-}$. Only at pH 11.9 is a distinct breakdown potential observed, an indicator of passivity. As discussed by Song et al. ${ }^{34}$ higher concentrations of $\mathrm{OH}^{-}$(i.e. higher $\mathrm{pH}$ ) assists in the maintenance of passive 
films in the presence of $\mathrm{Cl}^{-}$due to competition of these two anions at the solution-film interface. It has been shown in the literature ${ }^{17,32,35,36}$ that for

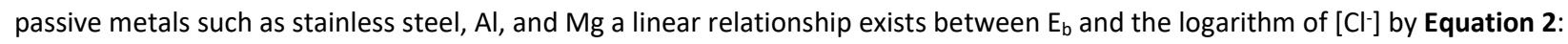

$$
E_{b}=A+B \log _{10}\left[\mathrm{Cl}^{-}\right]
$$

The gradient of the line, $B$, is therefore the dependence of $E_{b}$ on the logarithm of $\left[\mathrm{Cl}^{-}\right]$. Figure $7(i)$ shows the plot of $E_{b}$, obtained from potentiodynamic experiments, as a function of the logarithm of $\left[\mathrm{Cl}^{-}\right]$. Magnox has a $\left[\mathrm{Cl}^{-}\right]$dependence of $-0.229 \pm 0.026 \mathrm{~V} / \mathrm{decade}(95 \%, 2 \sigma)$ at $\mathrm{pH}$ 11.7 at room temperature. Analysis of the residuals showed a random distribution, and $R^{2}=\sim 1$. The dependence value obtained is larger than that observed with another Mg alloy AZ31v, along with commercial, and high-purity Mg metalsvi $\left(-0.072,-0.11,-0.11 \mathrm{~V} /\right.$ decade respectively). ${ }^{32}$ This significant difference is due to the alloy composition, which in turn has an impact on the structure or composition of the semi-protective film in the chloride environment. Characterisation performed in the current work using SEM-EDS identified a bilayer film structure, expected to be a thin layer of $\mathrm{MgO}$, with a thicker, more porous $\mathrm{Mg}(\mathrm{OH})_{2}$ outer layer. There is some evidence that the film(s) contain a small amount of Al. In comparison the AZ31 alloy composition contains a much larger concentration of Al -3 wt\% compared to $0.008 \mathrm{wt} \%$ in Magnox Al-80. Given that $\mathrm{Al}$ assists in passivity - when added below the solubility limit- ${ }^{31}$ there is likely a difference in passive film, which may explain the higher B value for Magnox Al80. To determine if there was a linear relationship between $E_{b}$ and temperature, a similar plot was generated, shown in Figure 7 (ii). Analysis of the data however indicated a poor fit. For the temperature dependence graph in Figure 7 (ii), $R^{2}=\sim 0.8$, and $-4.34 \pm 6.65 \mathrm{mV} / \mathrm{decade}(95 \%, 2 \sigma)$. The plot in Figure 7 (iii) shows $\mathrm{E}_{\text {corr }}$ as a function of $\mathrm{pH}$, undertaken as there was no clear relationship between $\mathrm{E}_{\mathrm{b}}$ and $\mathrm{pH}$. Figure $\mathbf{7}$ (iii) shows that a linear dependence appears to exist basic pHs (the result at pH 4 experiment was repeated multiple times, and similar results were observed each time). Excluding the result at $\mathrm{pH} 4$, Magnox shows a pH dependence of $-29 \pm 11 \mathrm{mV} /$ decade $(95 \%, 2 \sigma)$, with an $\mathrm{R}^{2}=\sim 1$.

\subsection{Electrochemical Impedance Spectroscopy}

EIS was undertaken to provide information on the passivity of the $\mathrm{Mg}$ alloy when immersed in basic solutions ( $\mathrm{NaOH})$ without $\mathrm{Cl}^{-}$. Figure 8 shows the evolution of real and imaginary impedance $\left(Z^{\prime}, Z^{\prime \prime}\right)$ over the course of 9 days in different concentrations of NaOH. The Nyquist plots show the change in the modulus of impedance $(|\mathrm{Z}|)$, which in most cases shows an increase between 1 and 2 days' immersion. The $10 \mathrm{ppm}[\mathrm{NaOH}]$ Nyquist plots show what appears to be a small half-semicircle at the highest frequencies, a semicircle at the medium frequency and a depressed semi-circle at the low frequency range, suggesting the presence of three time constants, with an inductive component at the low frequency. A sign possibly of localised corrosion. ${ }^{37,38}$ The plot obtained from immersion in 40 ppm [ $\mathrm{NaOH}$ ] shows a single time constant -it no longer shows the halfsemicircle at the high frequency, but still shows evidence of inductance at the low frequency range. The largest $|Z|$ is observed in the 200 ppm $[\mathrm{NaOH}]$ environment (Figure $\mathbf{8}(\mathbf{v})$ ), and has only a single time constant, without inductive behaviour at the low frequency.

King et al. ${ }^{38}$ combined EIS with hydrogen collection and specimen mass change. The authors investigated the response of high-purity Mg to $0.1,1.0$, and $5.0 \mathrm{~mol} \cdot \mathrm{dm}^{-3} \mathrm{NaCl}$ solutions (without $\mathrm{NaOH}$ ) over a 24 hour period. Increases in exposure time resulted in an increase in $|\mathrm{Z}|$ at the low frequency, along with an increase in inductance at the low frequency. The authors showed that the polarisation resistance was inversely proportional to $\mathrm{NaCl}$ concentration and used an equivalent circuit with multiple nested R-RC elements, combined with an inductive component (used to simulate the anodic reaction). Two different equivalent circuits were used, one for 0.1 and $1.0 \mathrm{~mol} \cdot \mathrm{dm}^{-3}$, and another for $5.0 \mathrm{~mol} \cdot \mathrm{dm}^{-3}$, which contained an additional RC element. Curioni et al. ${ }^{37}$ also undertook EIS combined with hydrogen collection to study 99.95 wt. \% Mg in 0.35

\footnotetext{
${ }^{\mathrm{V}}$ Experiments conducted at neutral $\mathrm{pH}$

${ }^{v i}$ Experiments conducted at $\mathrm{pH} 11$
} 
and $3.5 \% \mathrm{NaCl}$ using the 0.1 and $1.0 \mathrm{~mol} \cdot \mathrm{dm}^{-3}$ equivalent circuit proposed by King et al. ${ }^{38}$. In comparison to these earlier works, the current work sought to study the passive film formation in a high $\mathrm{pH}$, chloride-free environment, and so forgoes the inductive component. The observed results are consistent with the past work by Burrows ${ }^{14}$ and Burrows and Harris ${ }^{13}$, who performed ElS studies on Magnox in 40, 200 and 400 ppm [NaOH] for short time periods of up to 24 hours. These authors fitted their EIS data for Magnox in $\mathrm{NaOH}$ on the equivalent circuit model shown in Figure 9(i) for initial stages of passivation, ${ }^{13,14}$ and at longer time intervals indicated that a more simple R-RC equivalent circuit was appropriate ${ }^{14}$ as shown in Figure 9(ii). Note the use of a constant phase element (CPE) over a capacitor. Rosalbino et al. ${ }^{39}$, also applied a simple R-RC circuit with CPE in place of a capacitor to model EIS data obtained on rare earth containing $\mathrm{Mg}$ alloys exposed for up to 24 hours in pH 12 ( 400 ppm [NaOH]) NaOH solutions, which is approximately double the $\mathrm{NaOH}$ concentration that used here (c.f. $200 \mathrm{ppm}[\mathrm{NaOH}] \sim \mathrm{pH} 11.7$ ), but similar to that used by the previous authors. ${ }^{13,14}$ Pinto et al. ${ }^{26}$, studied rare earth containing $\mathrm{Mg}$ alloys in $\mathrm{NaOH}$ media, but using far more concentrated solutions ( $\mathrm{pH}$ 13, $\sim 4000 \mathrm{ppm}[\mathrm{NaOH}]$ ) and found that a double R-RC-RC circuit was more appropriate. These authors also used CPEs in place of capacitors. They explained their use of the double time constant circuit by the fact that the passive film was more stable in $\mathrm{NaOH}$ at $\mathrm{pH} 13$ than in $\mathrm{pH} 12$.

Based on the review of the literature, a simple R-RC equivalent circuit was applied to the EIS data so that the charge transfer resistance $\left(R_{t}\right)$ could be obtained (shown in Figure 9(ii)). The series resistor shown in Figure $\mathbf{9}(i i)$ acts as the solution resistance $\left(R_{s}\right)$, the resistor in series to this acts as $R_{t}$, whilst the parallel capacitor acts as the double layer capacitance $\left(C_{d l}\right)$. To simulate a poor capacitor a constant phase element was used with a fixed CPE-P value of 0.9. $R_{\mathrm{t}}$ was used to gain an indication of the specimen passivity with time (Figure 10). From the results it is evident that $\mathrm{Mg}$ alloy is more stable in the $200 \mathrm{ppm}[\mathrm{NaOH}]$ environment, which shows a distinct increase in $\mathrm{R}_{\mathrm{t}}$ after 48 hours and then stabilises for the rest of the 9 day period. The 200 ppm [ $\mathrm{NaOH}]$ experiment was allowed to run for an extended period of $>850$ hours ( $\sim 35$ days), the results of which are shown in Figure 11. The results show that measured $R_{t}$ after 9 days ( $\sim 60 \mathrm{k} \Omega$ ), doubles after 35 days to $\sim 1300 \mathrm{k} \Omega$.

\subsection{Time-lapse Imaging}

The results of the TLI matrix experiment are shown in Figure 12. After 2 days of immersion gas bubbles appear to be present on all of the specimens, which can be either: (i) attributed to degassing of the electrolyte, or, (ii) particularly in the lower pH solutions, attributed to $\mathrm{H}_{2}$ evolution which precedes film breakdown. Specimens in both the 10 and $40 \mathrm{ppm}[\mathrm{NaOH}]$ environments show a discoloration, darkening over time, compared to the specimens in the $200 \mathrm{ppm}[\mathrm{NaOH}]$ environment which retain their metallic lustre for a longer duration. It is apparent that in the 10 ppm [ $\mathrm{NaOH}], 40,60,80$ ppm [Cl-] environments corrosion initiation occurs over a short time period of 2 days. In $40 \mathrm{ppm}$ [NaOH] the specimen in

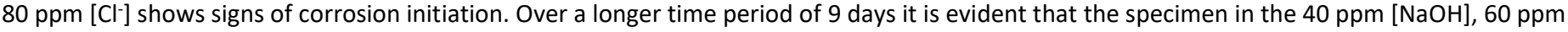

[Cl-] environment was affected by corrosion, due to gas evolution and surface darkening. Specimens in the $200 \mathrm{ppm}$ [NaOH] environment appeared unaffected throughout the experiment. In order to obtain further information on the extent of corrosion after 9 days, images were taken after the experiment had ended (total duration: 9 days, 20 hours), which are shown in Figure 13. Some of the specimens exposed to 10 and 40 ppm [NaOH] show a darkened surface with bright spots. It is expected that these bright spots are locations where gas bubbles were present on the surface from the cathodic reaction ( $\mathrm{H}_{2}$ evolution). One can observe that the stability of the $\mathrm{Mg}$ passive film, when exposed to $\mathrm{Cl}^{-}$, is clearly linked to the [ $\mathrm{NaOH}$, with passivity in the following order $200>40>10 \mathrm{ppm}[\mathrm{NaOH}]$. This is supported by the earlier potentiodynamic polarization and EIS experiments, where the higher $\mathrm{pH}$ environment was more beneficial for passivity. From these short-term experiments the critical [ $\left.\mathrm{Cl}^{-}\right]$for visible corrosion

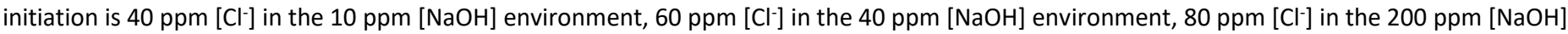
environment. Note that these experiments represent a less severe scenario than if a large volume of electrolyte was used due to the small specimen volume to electrolyte ratio in these simple experiments (alkalization effect). 


\subsection{Scanning Vibrating Electrode Technique}

The response of Magnox to immersion in $2.5 \% \mathrm{w} / \mathrm{v} \mathrm{NaCl}(\mathrm{aq})$ at $\mathrm{pH} 11.7$ is shown in Figure 14 . In the $\mathrm{j}_{z}$ plots obtained by SVET it can be seen that despite the high $\mathrm{pH}$, the high $\mathrm{Cl}^{-}$environment was sufficient to allow anodes to propagate along the surface. In Figure 14(i)-(v) two anodes which initiated on the top left of the surface, and propagated rightward with time. The surface did not show strong cathodic activity. As discussed by Laferrere et al., ${ }^{16}$ the lack of cathodic activity with SVET scans on Magnox may be due to the interaction of $\mathrm{H}_{2}$ with the probe (given the high current densities), or that the anode-cathode coupling is $<100 \mu \mathrm{m}$. By 12 hours (Figure 14(vi)) the specimen appeared to passivate, and for five hours thereafter, there was no new anode formation. Two anodes formed on the surface after 17 hours immersion, in a similar location as the first set of anodes, at the top left of the specimen. Figure 15(i) shows the propagation of these new anodes after 18 hours immersion. These anodes appear to follow the same tracks as those in Figure 14(i-v), although in these maps it is evident that the surface shows greater cathodic activity. Relating the results presented here to that obtained by Laferrere et al. ${ }^{16}$, who studied the Magnox in $2.5 \% \mathrm{w} / \mathrm{v} \mathrm{NaCl}(\mathrm{aq})$ without $\mathrm{NaOH}$ $(\mathrm{pH} 7)$, the anode intensities are similar, and the elevated $\mathrm{pH}$ appears to have had no impact on initiation time, or propagation of anodes. As with the previous work, there is no strong cathode behind the propagating anode, indicating the anode and cathode are weakly linked. The anode regions will be coupling therefore with a distributed cathode, observed over the majority of the visually intact Magnox surface. There is minimal evidence of cathodic activation of the filiform-like tracks immediately behind the advancing anodic regions. Thus the behavior at the elevated $\mathrm{pH}$ presented here shows little change from neutral, which is in contrast with other Mg alloys such as AZ31, where propagation rates and anodic/cathodic $\mathrm{j}_{\mathrm{z}}$ values decrease considerably when moving from neutral $\mathrm{pH}$ to $\mathrm{pH} 12 .^{33}$

Surface $\mathrm{j}_{\mathrm{z}}$ plots of the alloy are shown in Figure $\mathbf{1 6}$ for Magnox immersed in a $\mathrm{Cl}^{-}$electrolyte two orders of magnitude less concentrated (100 ppm [Cl], pH 11.7 NaOH). In the example shown here anodes formed within the first hour of scanning with SVET, indicating again that the high

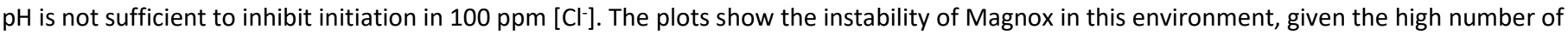
anodes which formed on the surface. There were however signs of dominant anodes which remained throughout the duration of the experiment, highlighted by the black arrows in Figure 16(i-vi). Once again there does not appear to be a strong link between the anode and cathodic sites, with the surface acting as a weak distributed cathode. In contrast to the earlier SVET experiment $j_{z}$ values are over one order of magnitude smaller, as one might expect, but also there is insufficient driving force for anode propagation along the surface. Plots of $j_{z}$ vs. distance across features are shown in Figure 17 which provide a more quantitative approach to comparing the changes in $\mathrm{j}_{z}$ with time. The plot ${ }^{\mathrm{vii}}$ shows both the static nature of these anodes over the course of 22 hours, but also the trend of increasing $\mathrm{j}_{\mathrm{z}}$ with time (up to $1.1 \mathrm{~A} \cdot \mathrm{m}^{-2}$ ). There is a small decrease in $\mathrm{j}_{\mathrm{z}}$ between 10 and 22 hours for the curve relating to the central anode in the plot, although the anodes either side at the extremes of the plot both show an increase in $\mathrm{j}_{\mathrm{z}}$ for the same time period (black arrows). Figure 18 shows the same type of plot ${ }^{\text {viii }}$ prepared from the higher [Cl-] data. What is evident is the greater peak $\mathrm{j}_{2}$ values (up to $50 \mathrm{~A} \cdot \mathrm{m}^{-2}$ ), and rapid anode propagation highlighted by the black arrow (>2 mm over a period of $140 \mathrm{minutes}$ ). The stationary nature of anodes in the low $\left[\mathrm{Cl}^{-}\right]$electrolyte is likely a combination of both low conductivity and the high $\mathrm{pH}$, which is now briefly discussed. Past work ${ }^{40}$ using SVET on commercial purity Mg has shown that for near-neutral $\mathrm{pH}$, there is a significant change in localised corrosion morphology from disc-like features to small filiform-like tracks with a reduction in [ $\left.\mathrm{Cl}^{-}\right]$. Importantly, even at the low [Cl-] these features remain mobile. In contrast, when [Cl-] is fixed and pH increased for an $\mathrm{Mg}$ alloy (AZ31) pit-like features have been shown to remain active for limited periods before passivating and initiating elsewhere. ${ }^{33}$ For Magnox there is likely a combination of both effects. The low conductivity causes these pit-like features to couple only to the visually intact Magnox in the immediate vicinity, whilst the high pH means that the visually intact Magnox

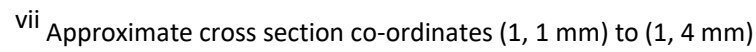

viii Approximate cross section co-ordinates $(0,7 \mathrm{~mm})$ to $(2,4 \mathrm{~mm})$
} 
surfaces adjacent to the anodes are less prone to breakdown. There may however also be a contribution from the chloride ion too, contributing to the change in corrosion mode (from stationary to propagating anodes) as rapid dissolution of the passive film can occur because of the greater concentration of $\mathrm{Cl}^{-}$. It is known that progressively increasing the chloride ion concentration renders $\mathrm{Mg}(\mathrm{OH})_{2} \mathrm{more}$ soluble. This is the explanation provided in ${ }^{32}$ to account for the logarithmic dependence of breakdown potential on $\left[\mathrm{Cl}^{-}\right]$. The same reason can help explain a possible chloride ion concentration effect - over and above increased electrolyte conductivity alone - on post-breakdown, localised corrosion propagation. For example, let us assume that deposition of $\mathrm{Mg}(\mathrm{OH})_{2}$ corrosion product is mainly responsible for the de-activation of local cathodic sites. It therefore follows that if a $\mathrm{Mg}(\mathrm{OH})_{2}$ corrosion product film forms less effectively at higher chloride concentrations, then regions of intense localised cathodic and anodic activity will remain "active" for longer, leading to more rapid rates of propagation.

Magnox demonstrated an increase in charge transfer resistance when exposed to high $\mathrm{pH}$ aqueous environments when no chloride is present. A longer duration experiment showed that the increase in charge transfer resistance continued to increase for longer immersion time in $200 \mathrm{ppm}[\mathrm{NaOH}](\mathrm{pH}$ 11.7) without chloride for periods of up to 35 days. These findings were supported by FIB cross-sectioning, which showed that the Magnox passive film thickness, which is predominantly $\mathrm{Mg}(\mathrm{OH})_{2}$, increases with time. The use of potentiodynamic polarisation in chloridecontaining electrolytes has shown that Magnox exhibits both a strong chloride ion dependence on breakdown potential, and passivity once the $\mathrm{pH}$ is sufficiently high. Using short, small-scale, TLI experiments in high pH chloride-containing electrolytes along with post corrosion imaging, it has been shown that Magnox passive film stability is greatest in $200 \mathrm{ppm}[\mathrm{NaOH}](\mathrm{pH} 11.7)$ when compared to $10 \mathrm{ppm}[\mathrm{NaOH}](\mathrm{pH} 10.4)$, consistent with the earlier EIS and potentiodynamic polarisation work. Finally, the characteristics of localised corrosion were explored using SVET at high pH. The work presented here was contrasted to the results of an earlier study of Magnox in neutral $\mathrm{pH}$, but at the same chloride concentration. ${ }^{16}$ It was found that at high chloride concentrations, the increased $\mathrm{pH}$ had little impact on initiation time, or anode propagation, which was rapid. Keeping $\mathrm{pH}$ constant, but significantly reducing the chloride concentration, showed that the high $\mathrm{pH}$ again did not decrease initiation time, although it did result in a decrease in anodic current density. The localised corrosion characteristics differed significantly in the low chloride electrolyte, highlighted by the stationary nature of the anodes, which is most likely due to a combination of the high pH, lower [Cl-], and the low conductivity. The low conductivity most likely causes these pit-like features to couple only to the visually intact Magnox in the immediate vicinity, whilst the high $\mathrm{pH}$ means that the visually intact Magnox surfaces adjacent to the anodes to be less prone to breakdown. In addition, at higher concentrations of $\mathrm{Cl}^{-}$, rapid film dissolution will occur, which allows for a change in corrosion mode from stationary anodes to propagating anodes.

The main aims of this work were to: (i) study Magnox Al-80 passivity, and (ii) study the dependence on [ $\left.\mathrm{Cl}^{-}\right]$, $\mathrm{pH}$ and localised corrosion characteristics. Addressing (i), it has been shown that pre-soaking Magnox Al-80 in 200 ppm [NaOH] -in the absence of Cl-- leads to the formation of a bilayer film structure which increases in thickness with time. As for (ii) Magnox Al-80 corrosion is strongly affected by the presence of $\mathrm{Cl}^{-}$, even when 200 ppm [ $\left.\mathrm{NaOH}\right]$ is used, however at $\leq 100$ ppm [Cl-] Magnox exhibits passivity, reflected in the d.c. electrochemistry and TLI studies. Further insight into the localised corrosion characteristics prior to film breakdown were provided by SVET, which showed the stationary

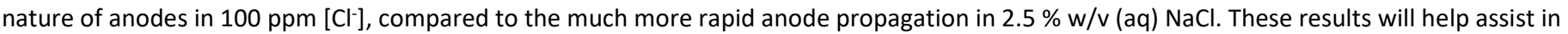
underpining the future waste fill levels for Magnox Al-80 waste swarf material. Firstly, the prior storage at high pH prior to retrievals may mean that the material has formed a thick protective bilayer film so that waste expansion is minimal, and secondly, what may happen if passivity is lost during subsequent interim storage. 


\section{CONCLUSIONS}

Magnox Al-80 exhibited an increase in charge transfer resistance with immersion time, in $\mathrm{NaOH}$ containing electrolytes when no chloride was added to the system. The greatest charge transfer resistance was observed in $200 \mathrm{ppm}[\mathrm{NaOH}](\mathrm{pH} 11.7)$.

Magnox Al-80 was characterized following aqueous exposure to $\mathrm{NaOH}$ solutions using FIB cross sectioning, which showed the presence of a dual film structure, expected to largely consist of $\mathrm{Mg}(\mathrm{OH})_{2}$. This combined film thickness increased with immersion time, which is in line with the observed increase in charge transfer resistance obtained by EIS.

Time-lapse and post corrosion imaging showed that higher concentrations of $\mathrm{NaOH}$ assist in Magnox Al-80 stability in solutions where chloride is present. Based on these short, small-scale experiments additions of $200 \mathrm{ppm}[\mathrm{NaOH}](\mathrm{pH} 11.7)$ increase the critical chloride concentration for Magnox passivity breakdown.

Magnox Al-80 passive behavior at high pH (pH 11.7 (200 ppm [NaOH])) was demonstrated through potentiodynamic experiment. Magnox Al-80 exhibited a strong chloride ion dependence on breakdown potential of $-0.229 \pm 0.026 \mathrm{~V} /$ decade $(95 \%, 2 \sigma)$.

SVET experiments allowed localized corrosion initiation and propagation to be characterized. In both a low (100 ppm [Cl-]), and high chloride $(2.5 \% \mathrm{w} / \mathrm{v}(\mathrm{aq}))$ environments, high $\mathrm{pH}(\mathrm{pH} 11.7)$ was insufficient to stop or minimize anode initiation time. At the high chloride concentration there was rapid propagation of anodes, whilst at the low concentration anodes remained stationary.

$>\quad$ At high $\mathrm{pH}$ where Magnox Al-80 exhibits passivity, it is thought that at low chloride concentrations anodes which form are only able to couple to the visually intact surface in the vicinity of the anode, due to the low conductivity the electrolyte. The high $\mathrm{pH}$ means that the visually intact Magnox in the vicinity is less prone to breakdown, restricting anode propagation such that they remain largely static. In high chloride concentrations the high conductivity means that the anode and cathode can couple over greater distances and so propagation along the surface can occur at a much faster rate, with the visually intact surface acting as a distributed cathode. Additionally, the chloride anion itself allows for rapid film dissolution at the higher chloride concentration, allowing for more rapid anode propagation.

\section{ACKNOWLEDGMENTS}

The authors would like to thank Dr Keith Hallam (University of Bristol) for assistance running XRD instrumentation. Dr Peter Heard (University of Bristol) and Dr Tomas Martin (University of Bristol) are both acknowledged for their assistance running the FIB-SEM. Financial support is acknowledged from EPSRC and the European Social Fund through the Materials and Manufacturing Academy (M2A) Centre for Doctoral Training for James Humpage. The authors also acknowledge funding from the UK National Nuclear Laboratory Limited and Sellafield Ltd. This paper was published with permission from the UK National Nuclear Laboratory Limited and Sellafield Ltd.

\section{REFERENCES}

1. Nuclear Decommissioning Authority. The Magnox Operating Programme 9 (MOP 9).; 2012. 
3. Song GL. Corrosion Electrochemistry of Magnesium (Mg) and Its Alloys. Woodhead Publishing Limited; 2011. doi:10.1533/9780857091413.1.3

4. Yang SA, Lin CS. Effect of fluoride ion on the microstructure and properties of permanganate conversion coating on AZ91D magnesium alloy. In: Minerals, Metals and Materials Series. Vol Part F7. Springer International Publishing; 2018:37-42. doi:10.1007/978-3-319-723327_8

5. Allen GC. Surface analysis of etched Magnox alloys by secondary ion mass spectrometry and ion scattering spectroscopy. Metal Science. 1984;18(6):295-298. doi:10.1179/030634584790419980

6. Hallam KR, Minshall PC, Heard PJ, Flewitt PEJ. Corrosion of the alloys Magnox AL80, Magnox ZR55 and pure magnesium in air containing water vapour. Corrosion Science. 2016;112:347-363. doi:10.1016/j.corsci.2016.07.033

7. Bradford PM, Case B, Dearnaley G, Turner JF, Woolsey IS. Ion beam analysis of corrosion films on a high magnesium alloy (Magnox Al 80). Corrosion Science. 1976;16(10):747-766. doi:10.1016/0010-938X(76)90007-X

8. Majchrowski TP. Chemical Behaviour of a Nuclear-grade Magnesium Alloy during Storage. 2015.

9. Jarjis RA. Fluorine concentration profile determination in MAGNOX reactor fuel canning material. Journal of Radioanalytical Chemistry. 1979;48(1-2):311-315. doi:10.1007/BF02519795

10. Case B, Hilton DA. Water Chemistry Control and Corrosion Inhibition in Magnox Fuel Storage Ponds. In: British Nuclear Energy Society: Water Chemistry of Nuclear Reactor Systems. Thomas Telford Publishing; 1978:429-436. doi:10.1680/wconrs.00537.0056

11. Friskney CA, Pearce RJ, Robins IH, Simpson KA. The Corrosion of Magnox Al-80 Alloy in Aqueous and Moist Environments. In: Gas-Cooled Reactors Today. British Nuclear Energy Society; 1982:77-82. doi:10.1680/GCRTV1.01657.0010

12. Burrows R, Harris S, Stevens NPC. Corrosion electrochemistry of fuel element materials in pond storage conditions. Chemical Engineering Research and Design. 2005;83(7 A):887-892. doi:10.1205/cherd.05023

13. Burrows R, Harris S. Electrochemical Corrosion Study of Magnox Al80 and Natural Uranium. In: Electrochemistry in Light Water Reactors. Elsevier; 2007:156-163. doi:10.1533/9781845693022.2.156

14. Burrows R. Passive and Localised Corrosion Behaviour of a High Magnesium alloy (Magnox AL80). 2013. https://www.research.manchester.ac.uk/portal/files/54539606/FULL_TEXT.PDF.

15. Kirby C. Galvanic and crevice corrosion effects in Magnox A180 alloy. Corrosion Science. 1987;27(6):567-583. doi:10.1016/0010938X(87)90031-X

16. Laferrere A, Burrows R, Glover C, et al. In situ imaging of corrosion processes in nuclear fuel cladding. Corrosion Engineering Science and Technology. 2017;52(8):596-604. doi:10.1080/1478422X.2017.1344038

17. Williams G, McMurray HN. Pitting Corrosion of Steam Turbine Blading Steels: The Influence of Chromium Content, Temperature, and Chloride Ion Concentration. CORROSION. 2006;62(3):231-242. doi:10.5006/1.3278269

18. Williams G, Neil McMurray H. Localized Corrosion of Magnesium in Chloride-Containing Electrolyte Studied by a Scanning Vibrating Electrode Technique. Journal of The Electrochemical Society. 2008;155(7):C340. doi:10.1149/1.2918900

19. Clark RN, Searle J, Martin TL, Walters WS, Williams G. The role of niobium carbides in the localised corrosion initiation of $20 \mathrm{Cr}-25 \mathrm{Ni}-\mathrm{Nb}$ advanced gas-cooled reactor fuel cladding. Corrosion Science. 2020;165:108365. doi:10.1016/j.corsci.2019.108365

20. Clark RN, May Chan C, Martin TL, et al. The Effect of Sodium Hydroxide on Niobium Carbide Precipitates in Thermally Sensitised 20Cr-25NiNb Austenitic Stainless Steel. Corrosion Science. 2020:108596. doi:10.1016/j.corsci.2020.108596

21. Unocic KA, Elsentriecy HH, Brady MP, et al. Transmission Electron Microscopy Study of Aqueous Film Formation and Evolution on Magnesium Alloys. Journal of The Electrochemical Society. 2014;161(6):C302-C311. doi:10.1149/2.024406jes

22. Phillips RC, Kish JR. Nature of surface film on matrix phase of Mg alloy AZ80 formed in water. Corrosion. 2013;69(8):813-820. doi:10.5006/0938

23. Song GL, Unocic KA. The anodic surface film and hydrogen evolution on Mg. Corrosion Science. 2015;98:758-765. 
doi:10.1016/j.corsci.2015.05.047

24. Brady MP, Rother G, Anovitz LM, et al. Film Breakdown and Nano-Porous $\mathrm{Mg}(\mathrm{OH}) 2$ Formation from Corrosion of Magnesium Alloys in Salt Solutions. Journal of The Electrochemical Society. 2015;162(4):C140-C149. doi:10.1149/2.0171504jes

25. Taheri M, Phillips RC, Kish JR, Botton GA. Analysis of the surface film formed on Mg by exposure to water using a FIB cross-section and STEM-EDS. Corrosion Science. 2012;59:222-228. doi:10.1016/j.corsci.2012.03.001

26. Pinto R, Ferreira MGS, Carmezim MJ, Montemor MF. Passive behavior of magnesium alloys (Mg-Zr) containing rare-earth elements in alkaline media. Electrochimica Acta. 2010;55(7):2482-2489. doi:10.1016/j.electacta.2009.12.012

27. Brady MP, Fayek M, Elsentriecy HH, et al. Tracer Film Growth Study of Hydrogen and Oxygen from the Corrosion of Magnesium in Water. Journal of The Electrochemical Society. 2014;161(9):C395-C404. doi:10.1149/2.0821409jes

28. Seyeux A, Liu M, Schmutz P, Song G, Atrens A, Marcus P. ToF-SIMS depth profile of the surface film on pure magnesium formed by immersion in pure water and the identification of magnesium hydride. Corrosion Science. 2009;51(9):1883-1886.

doi:10.1016/j.corsci.2009.06.002

29. Taheri M, Phillips RC, Kish JR, Botton GA. Analysis of the surface film formed on Mg by exposure to water using a FIB cross-section and STEM-EDS. Corrosion Science. 2012;59:222-228. doi:10.1016/j.corsci.2012.03.001

30. Cao F, Song GL, Atrens A. Corrosion and passivation of magnesium alloys. Corrosion Science. 2016;111:835-845. doi:10.1016/j.corsci.2016.05.041

31. Gusieva K, Davies CHJ, Scully JR, Birbilis N. Corrosion of magnesium alloys: the role of alloying. International Materials Reviews. 2015;60(3):169-194. doi:10.1179/1743280414Y.0000000046

32. Williams G, Dafydd HAL, Subramanian R, Mcmurray HN. The Influence of Chloride lon Concentration on Passivity Breakdown in Magnesium. Corrosion. 2017;73(5):471-482. doi:http://dx.doi.org/10.5006/2328

33. Williams G, Dafydd HAL, Grace R. The localised corrosion of Mg alloy AZ31 in chloride containing electrolyte studied by a scanning vibrating electrode technique. Electrochimica Acta. 2013;109:489-501. doi:10.1016/j.electacta.2013.07.134

34. Song G, Atrens A, St. John D, Wu X, Nairn J. The anodic dissolution of magnesium in chloride and sulphate solutions. Corrosion Science. 1997;39(10-11):1981-2004. doi:10.1016/S0010-938X(97)00090-5

35. Clark RN. Mapping of Corrosion Sites in Advanced Gas-cooled Reactor Fuel Cladding in Long Term Pond Storage. 2018. doi:10.23889/SUthesis.40783

36. Newman RC. Understanding the corrosion of stainless steel. Corrosion. 2001;57(12):1030-1041. doi:10.5006/1.3281676

37. Curioni M, Scenini F, Monetta T, Bellucci F. Correlation between electrochemical impedance measurements and corrosion rate of magnesium investigated by real-time hydrogen measurement and optical imaging. Electrochimica Acta. 2015;166:372-384. doi:10.1016/j.electacta.2015.03.050

38. King AD, Birbilis N, Scully JR. Accurate electrochemical measurement of magnesium corrosion rates; A combined impedance, mass-loss and hydrogen collection study. Electrochimica Acta. 2014;121:394-406. doi:10.1016/j.electacta.2013.12.124

39. Rosalbino F, Angelini E, De Negri S, Saccone A, Delfino S. Electrochemical behaviour assessment of novel Mg-rich Mg-Al-RE alloys (RE = Ce, Er). Intermetallics. 2006;14(12):1487-1492. doi:10.1016/j.intermet.2006.01.056

40. Williams G, Birbilis N, McMurray HN. Controlling factors in localised corrosion morphologies observed for magnesium immersed in chloride containing electrolyte. Faraday Discussions. 2015;180:313-330. doi:10.1039/c4fd00268g

41. Meites EL. Handbook of Analytical Chemistry. McGraw-Hill Inc.,US; 1963. 


\section{FIGURE CAPTIONS}

FIGURE 1. EIS script, where $\mathrm{n}$ refers to the number of iterations

FIGURE 2. Time-lapse photography set-up

FIGURE 3. X-ray diffraction spectra for (i) a specimen exposed to $200 \mathrm{ppm}$ [NaOH] for a period of one year, (ii) control specimen (pickled).

The curve for the specimen is shown in blue, $\mathrm{Mg}$ peaks are in red, and $\mathrm{Mg}(\mathrm{OH})_{2}$ are shown in green

FIGURE 4. FIB-SEM cross sections of Magnox exposed to 200 ppm [NaOH] following (i, ii) 3 days immersion, (iii, iv) 10 weeks immersion, $(v$, iv) 1 year immersion. These images were taken using the secondary electron and InLens detectors. (ii, iv, vi) are high magnification images of the cross section between the Pt layer and specimen. Note that the magnification scale bars are not necessarily the same size

FIGURE 5. SEM-EDS analysis of Magnox Al-80 following exposure to $200 \mathrm{ppm}[\mathrm{NaOH}]$ for a period of one year

FIGURE 6 Typical response of Magnox alloy to potentiodynamic polarization (i) in 10, 100, 1000, $5000 \mathrm{ppm}\left[\mathrm{Cl}^{-}\right]$, at $20^{\circ} \mathrm{C}, \mathrm{pH} 11.7$, (ii) at

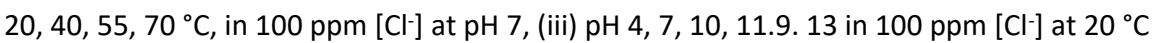

FIGURE 7. Breakdown potentials as a function of: (i) $\log \left[\mathrm{Cl}^{-}\right]$and (ii) temperature. (iii) OCP as a function of pH. Error bars represent one standard deviation

FIGURE 8. EIS data obtained over a period of 9 days. Nyquist and Bode plots for (i, ii) 10 ppm NaOH, (iii, iv) 40 ppm NaOH, (v, vi) 200 ppm $\mathrm{NaOH}$. Nyquist plots are shown on the left, the Bode plots on the right. Note that the axis range is different for each environment

FIGURE 9. Equivalent circuit models used by Burrows ${ }^{14}$ and Burrows et al. ${ }^{13}$

FIGURE 10. Charge transfer resistance $\left(R_{t}\right)$ obtained from EIS analysis as a function of time for (i) different [ $\mathrm{NaOH}$ ] over a nine day period, (ii) an extended period of 35 days in $200 \mathrm{ppm}$ [NaOH]. Error bars are present in the datapoints over the course of a 9 day period, and relate to the goodness of fit to the equivalent circuit. The gap in the data between 500 and 650 hours was because the electrochemical cell was removed from the potentiostat so that another experiment could be undertaken. After the experiment was complete, the EIS experiment was restarted with the same electrochemical cell.

FIGURE 11. TLI experiment showing the impact of $\left[\mathrm{Cl}^{-}\right]$and $[\mathrm{NaOH}]$ as a matrix over the course after (i) two days, (ii) nine days. Horizontally (from left to right) the $\left[\mathrm{Cl}^{-}\right]$is $10,20,40,60,80 \mathrm{ppm}$, and vertically (top to bottom) 10, 40, $200 \mathrm{ppm}[\mathrm{NaOH}]$

FIGURE 12. Post corrosion macro images of TLI specimens following immersion for 9 days and 20 hours, showing the top and bottom of the specimens. The specimens were of similar size. Each division on the scale bar is $1 \mathrm{~mm}$ (scale bar not shown for the $80 \mathrm{ppm}\left[\mathrm{Cl}^{-}\right], 10 \mathrm{ppm}\left[\mathrm{NaOH}^{-}\right.$ specimens)

FIGURE 13. SVET normal current density $\mathrm{j}_{\mathrm{z}}$ maps of Magnox in $2.5 \% \mathrm{w} / \mathrm{v}$ (aq) $\mathrm{NaCl}$, at pH 11.7 (i) 2, (ii) 4, (iii) 6, (iv) 8, (v) 10, (vi) 12 hours immersion

FIGURE 14. SVET normal current density $\mathrm{j}_{z}$ maps of Magnox in $2.5 \% \mathrm{w} / \mathrm{v} \mathrm{NaCl}$ (aq), at pH 11.7 (i) 18, (ii) 20, (iii) 22, (iv) 24 hours immersion

FIGURE 15. SVET normal current density $\mathrm{j}_{z}$ maps of the Magnox in $100 \mathrm{ppm}\left[\mathrm{Cl}^{-}\right]$at $\mathrm{pH}$ 11.7. The black arrows denote dominant static anodes. (i) 2, (ii) 4, (iii) 6, (iv) 16, (v) 18, (vi) 20 hours immersion 
FIGURE 16. SVET-derived normal current density $\mathrm{j}_{2}$ cross sectional profiles showing the static nature of anodes from the specimen exposed to 100 ppm [Cl-] for up to 22 hours. The black arrows highlight the static nature of the anodes

FIGURE 17. SVET-derived normal current density $\mathrm{j}_{2}$ cross sectional profiles showing rapid propagation of anodes from the specimen exposed to $2.5 \% \mathrm{w} / \mathrm{v}(\mathrm{aq})$ over 140 minutes. The black arrow highlights the propagation of anodes from left to right

\section{TABLES}

Table 1. Typical composition of Magnox Al-80 fuel cladding ${ }^{16}$

Table 2. Summary of characterization methods and experiments performed in this work

Table 3. Observed and corrected overall film thicknesses measured using FEG-SEM on FIB-SEM cross sectioned specimens exposed to 200 $\mathrm{ppm}[\mathrm{NaOH}]$ for different durations at room temperature. The uncertainty is given as the standard deviation of three measurements taken along the cross section 
Table 1

\begin{tabular}{|c|c|}
\hline Magnox Al-80 & Wt\% \\
\hline $\mathbf{Z n}$ & 0.008 \\
\hline $\mathbf{A l}$ & 0.77 \\
\hline $\mathbf{S i}$ & $<0.08$ \\
\hline $\mathbf{C u}$ & $<0.005$ \\
\hline $\mathbf{M n}$ & $<0.005$ \\
\hline $\mathbf{F e}$ & $<0.005$ \\
\hline $\mathbf{S n}$ & $<0.005$ \\
\hline $\mathbf{B i}$ & $<0.002$ \\
\hline $\mathbf{B e}$ & 0.003 \\
\hline $\mathbf{C a}$ & $<0.005$ \\
\hline $\mathbf{Z r}$ & - \\
\hline
\end{tabular}


Table 2

\begin{tabular}{|c|c|c|c|c|}
\hline Technique & $\begin{array}{l}\text { Chloride } \\
\text { concentration }\end{array}$ & pH & Temperature & Aim of characterization/experiment \\
\hline X-ray diffraction & $0 \mathrm{ppm}$ & 11.7 & \multirow{2}{*}{ Room temperature } & $\begin{array}{l}\text { Study the crystal structure of the corrosion film after aqueous exposure } \\
\text { to } \mathrm{NaOH} \text { for a period of } 1 \text { year without } \mathrm{Cl}^{-}\end{array}$ \\
\hline $\begin{array}{l}\text { FIB-SEM milling/FEG-SEM } \\
\text { imaging }\end{array}$ & $0 \mathrm{ppm}$ & 11.7 & & $\begin{array}{l}\text { Study the corrosion film thickness after aqueous exposure to } \mathrm{NaOH} \\
\text { without } \mathrm{Cl}^{-} \text {for various durations ( } 4 \text { day, } 10 \text { weeks, } 1 \text { year) }\end{array}$ \\
\hline \multirow[t]{3}{*}{$\begin{array}{l}\text { Potentiodynamic } \\
\text { polarization }\end{array}$} & $100 \mathrm{ppm}$ & 7 & $20,40,55,70^{\circ} \mathrm{C}$ & Study the effect of temperature on Magnox corrosion \\
\hline & $\begin{array}{l}0,10,100,1000,5000 \\
\text { ppm }\end{array}$ & 11.7 & \multirow{5}{*}{ Room temperature } & Study the effect of chloride on Magnox at high $\mathrm{pH}$ \\
\hline & $100 \mathrm{ppm}$ & $\begin{array}{l}4,7,10 \\
11.9,13\end{array}$ & & Study the effect of $\mathrm{pH}$ on Magnox corrosion \\
\hline EIS & $0 \mathrm{ppm}$ & $\begin{array}{c}10.4,11 \\
11.7\end{array}$ & & Study formation of passive film on Magnox up to 1 month without $\mathrm{Cl}^{-}$ \\
\hline SVET & $\begin{array}{l}100 \mathrm{ppm}[\mathrm{Cl}], 2.5 \% \\
\mathrm{w} / \mathrm{v} \text { (aq) } \mathrm{NaCl}\end{array}$ & 11.7 & & $\begin{array}{l}\text { Study localised corrosion on Magnox in high } \mathrm{pH} \mathrm{NaOH} \text { environment } \\
\text { with (a) high }[\mathrm{Cl}] \text {, and (b) low }\left[\mathrm{Cl}^{-}\right]\end{array}$ \\
\hline TLI & $10,20,40,60,80 \mathrm{ppm}$ & $\begin{array}{c}10.4,11 \\
11.7\end{array}$ & & Study the passive film characteristics \\
\hline
\end{tabular}


Table 3

\begin{tabular}{|c|c|c|}
\hline Exposure duration & Film thickness observed, $\mathbf{n m}$ & Corrected film thickness, $\mathbf{n m}$ \\
\hline 3 day & $74 \pm 13$ & $105 \pm 18$ \\
\hline 10 weeks & $208 \pm 13$ & $294 \pm 18$ \\
\hline 1 year & $397 \pm 71$ & $561 \pm 101$ \\
\hline
\end{tabular}




\section{FIGURES}
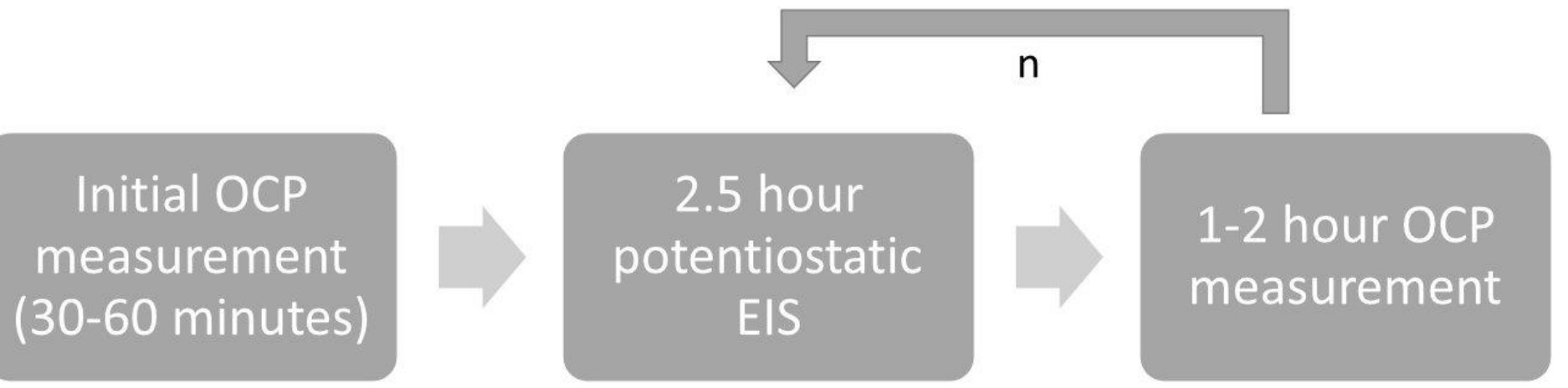

Figure 1 
(i) Cross section view

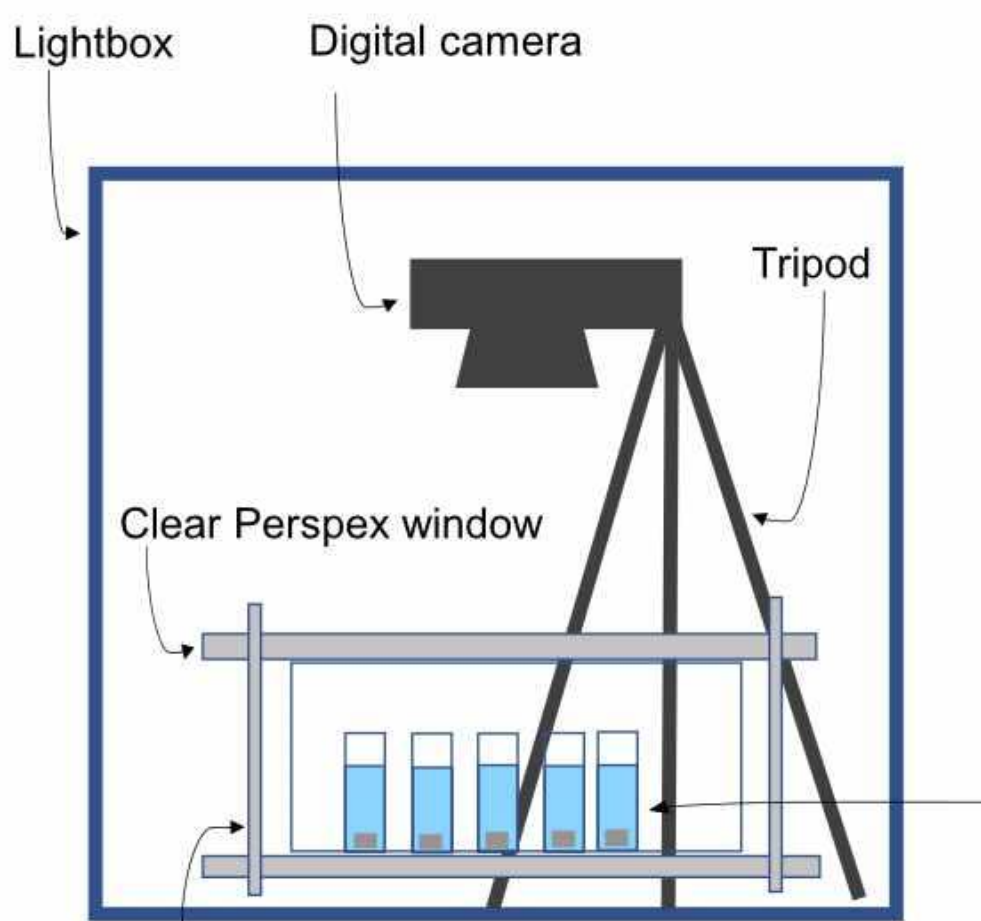

Clamping arrangement (ii) Top-down view

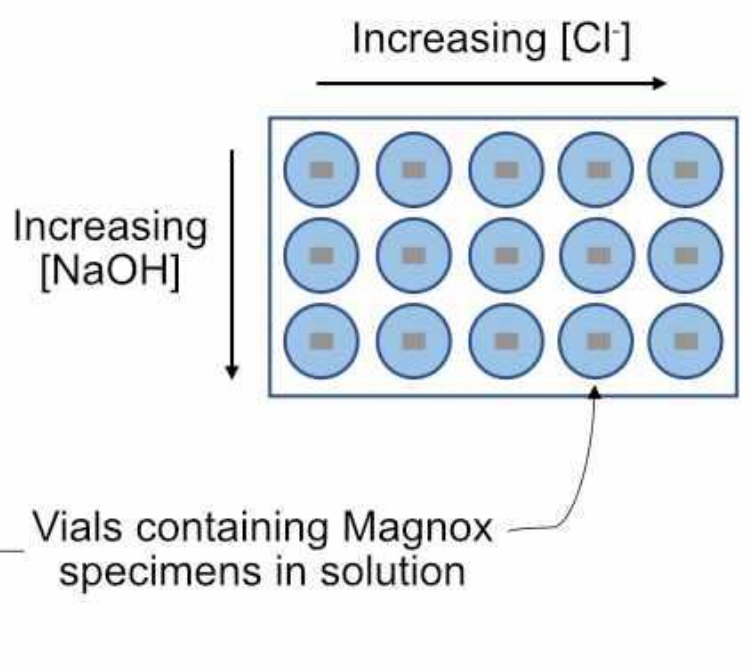
specimens in solution

Figure 2 


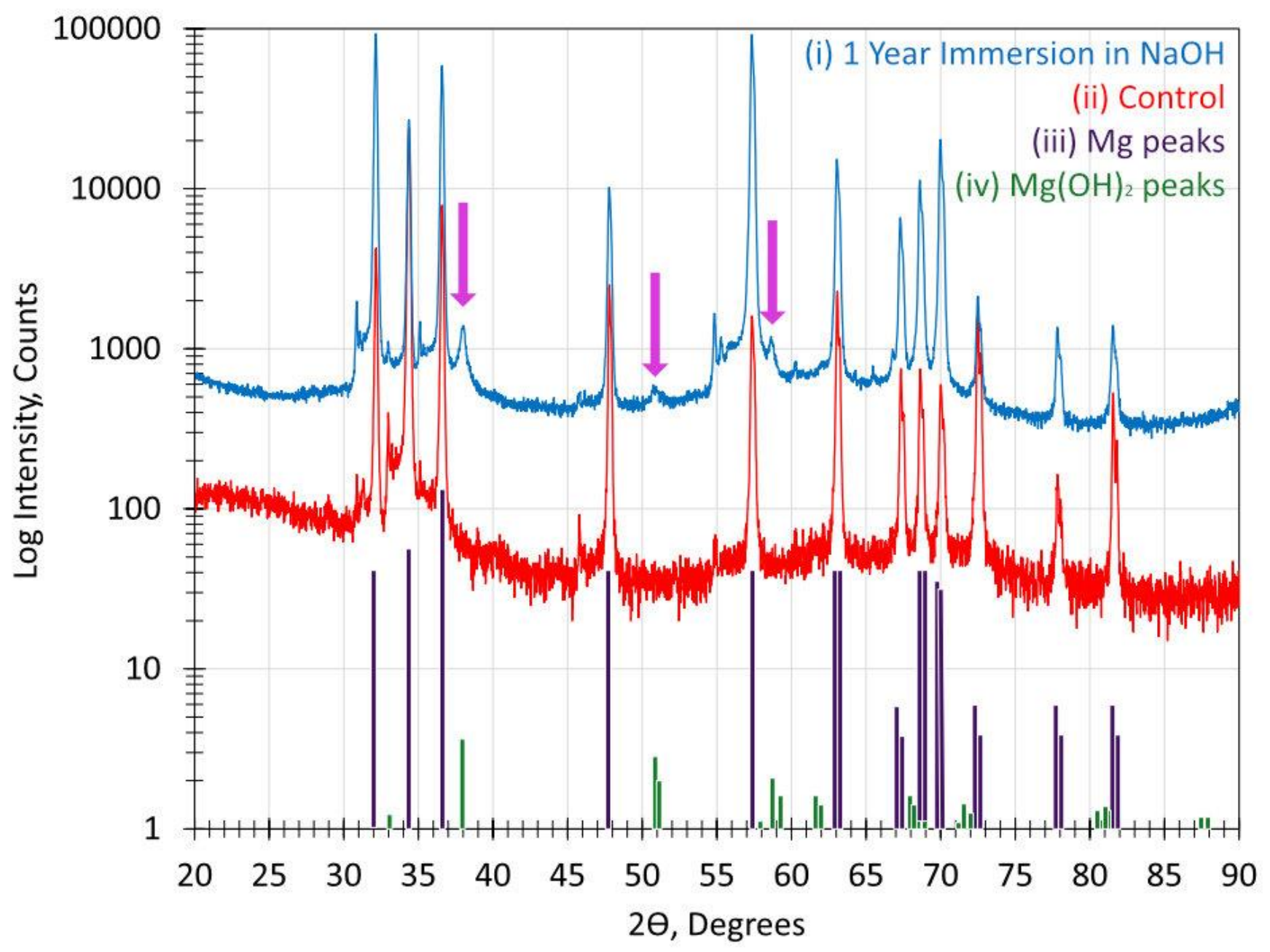

Figure 3 


\section{3 day immersion}

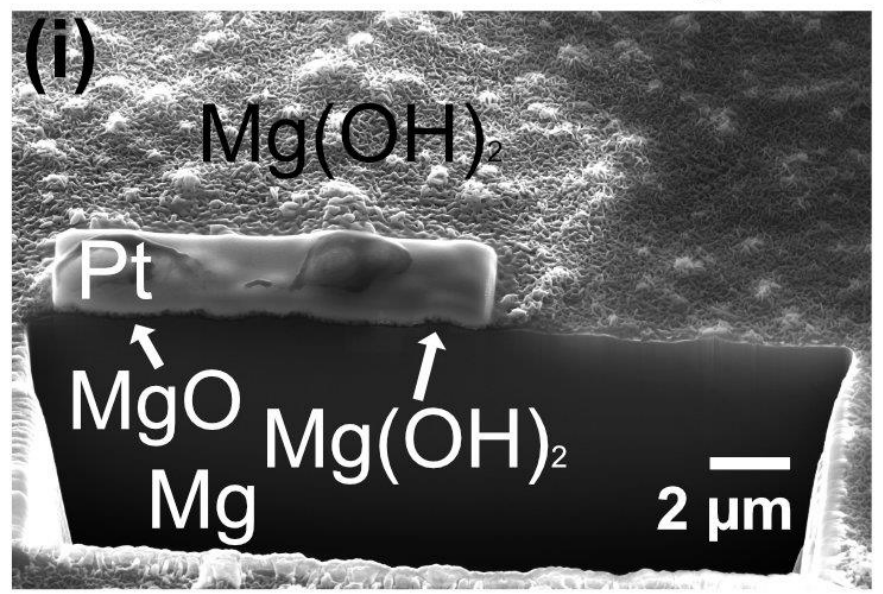

(ii)

$\mathrm{Pt}$

$\mathrm{Mg}(\mathrm{OH})_{2}$

$\mathrm{Mg}$

\section{0 week immersion}
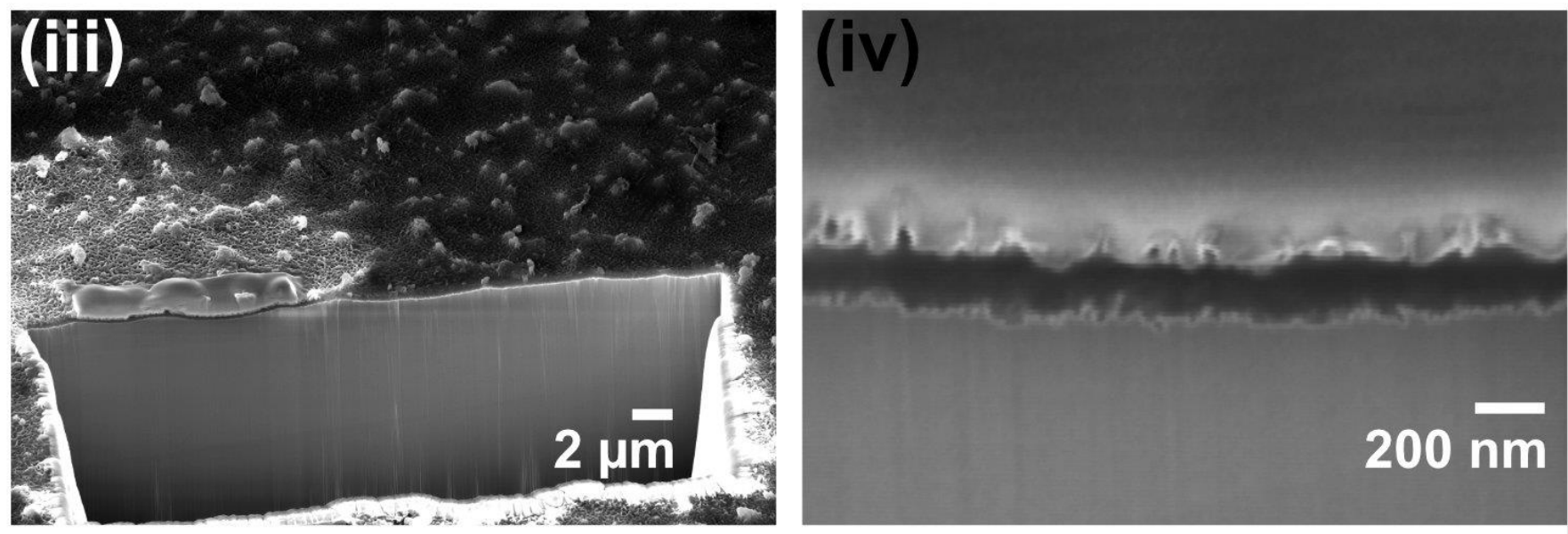

\section{1 year immersion}

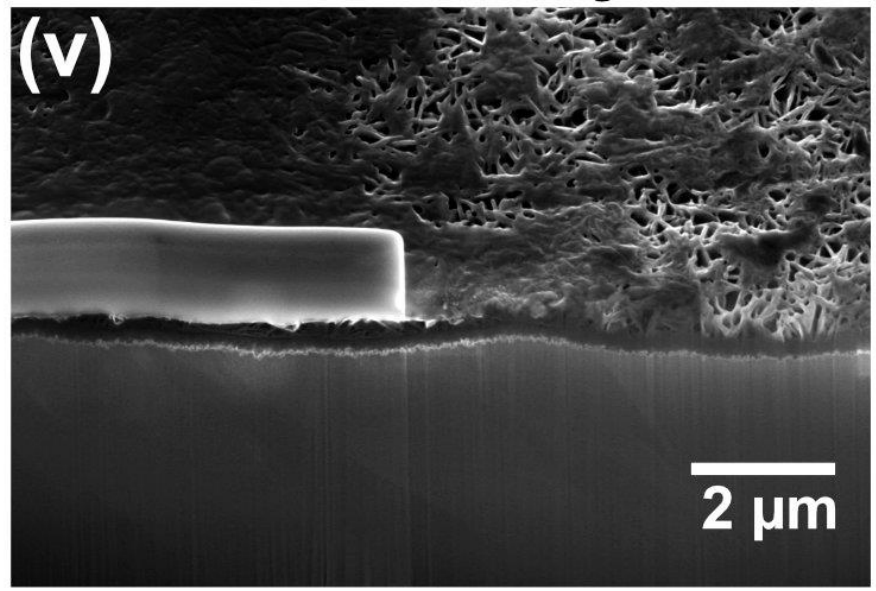



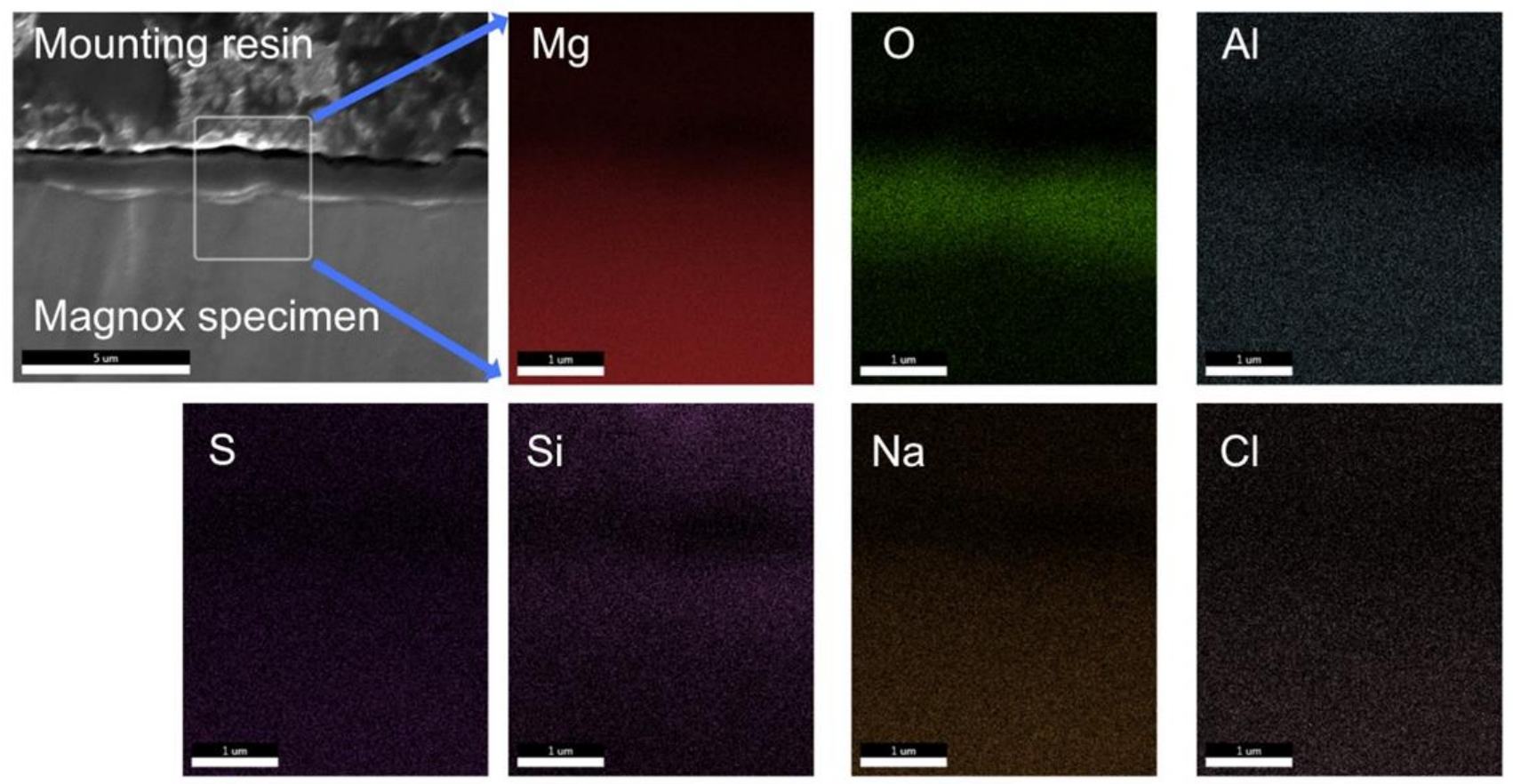

Figure 5 
(i)

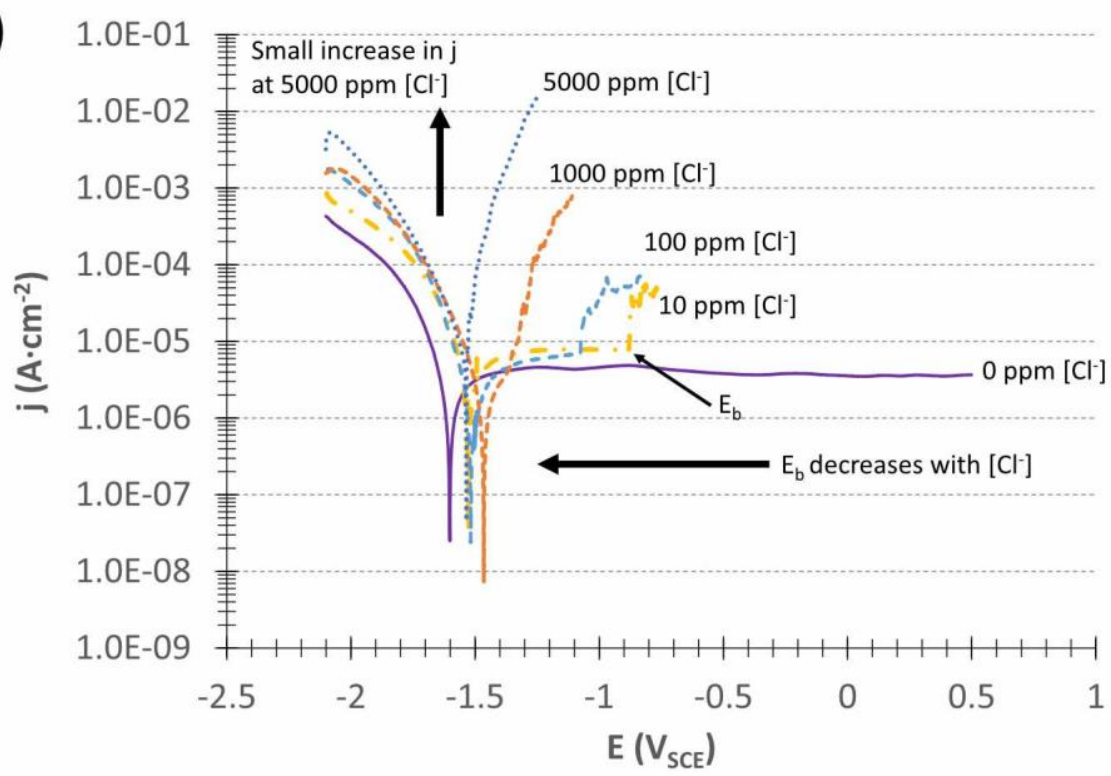

(ii)
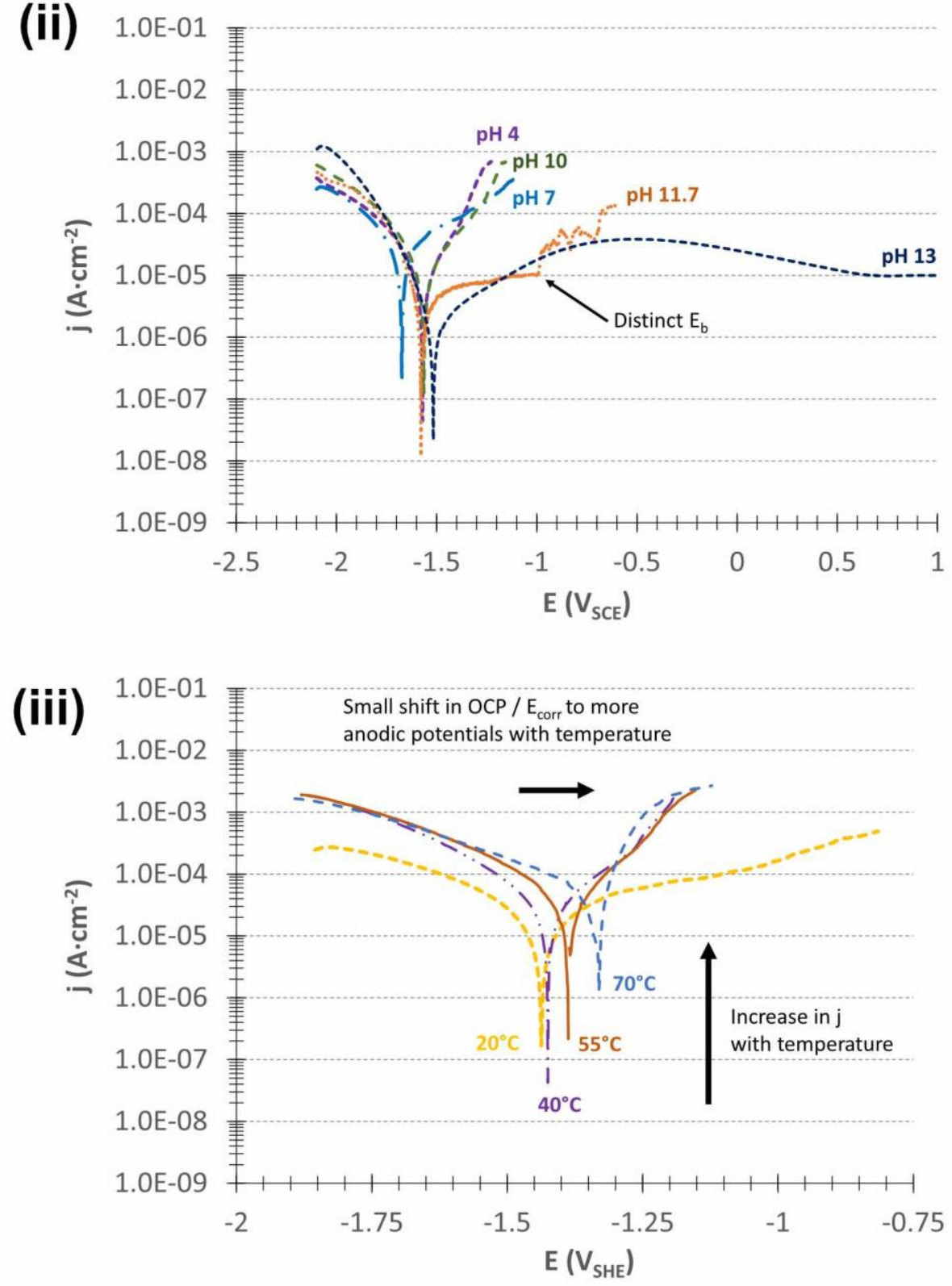

Figure 6 

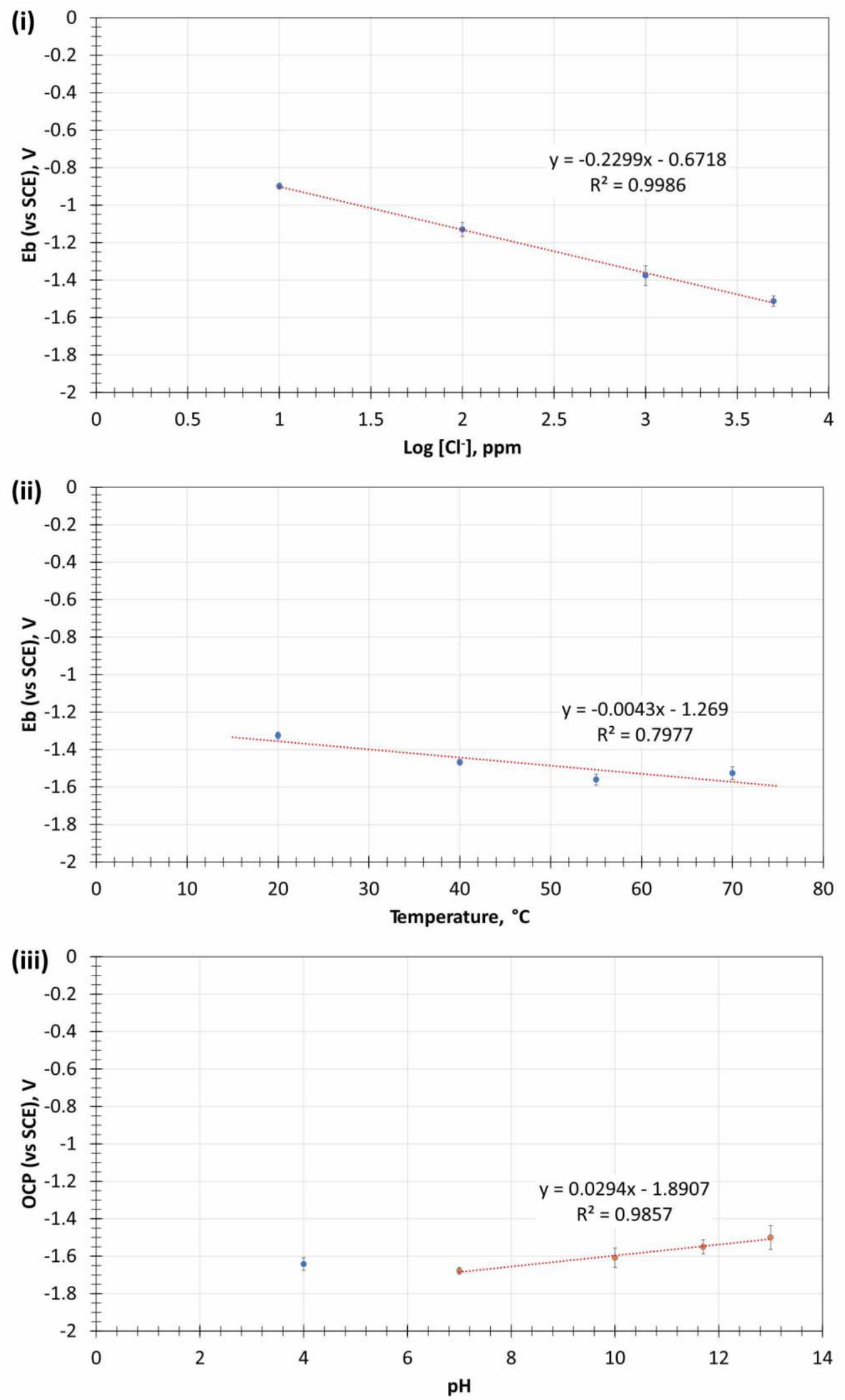

Figure 7 


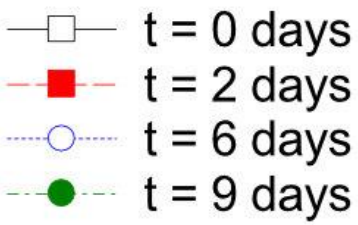

(i)

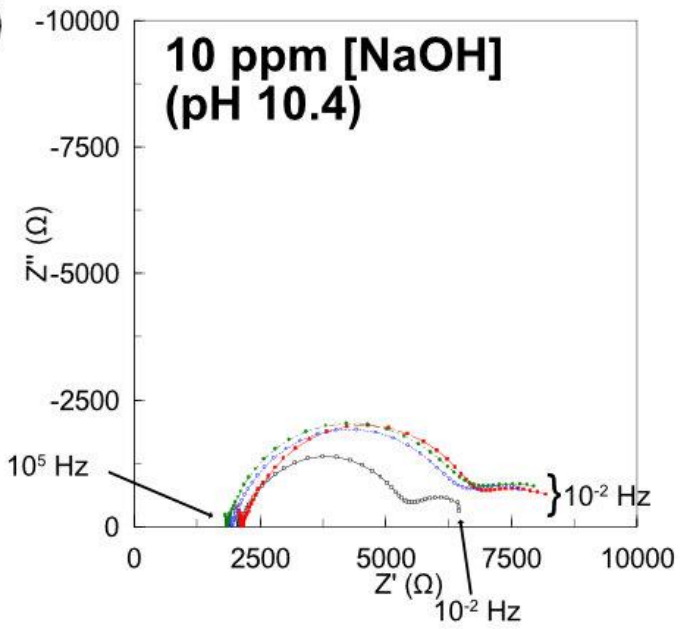

(iii)
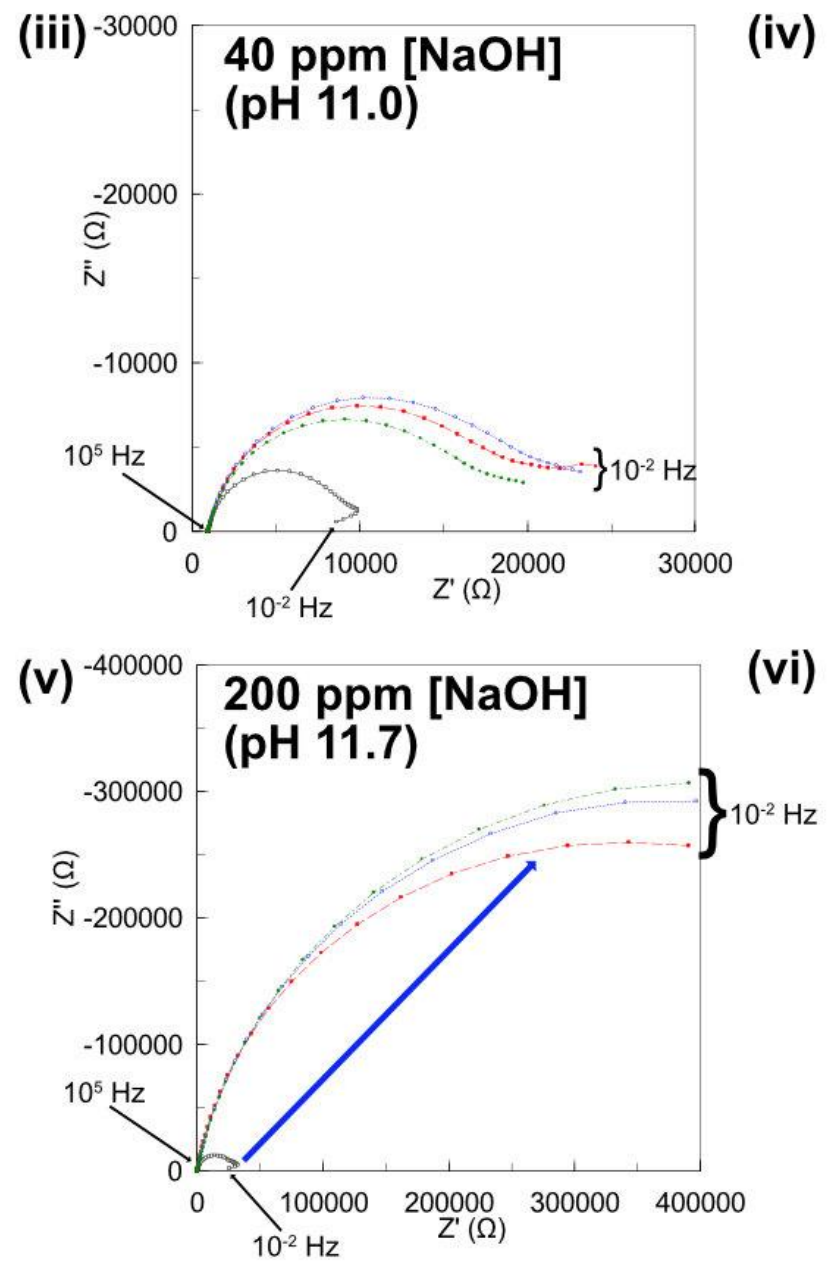

(ii)
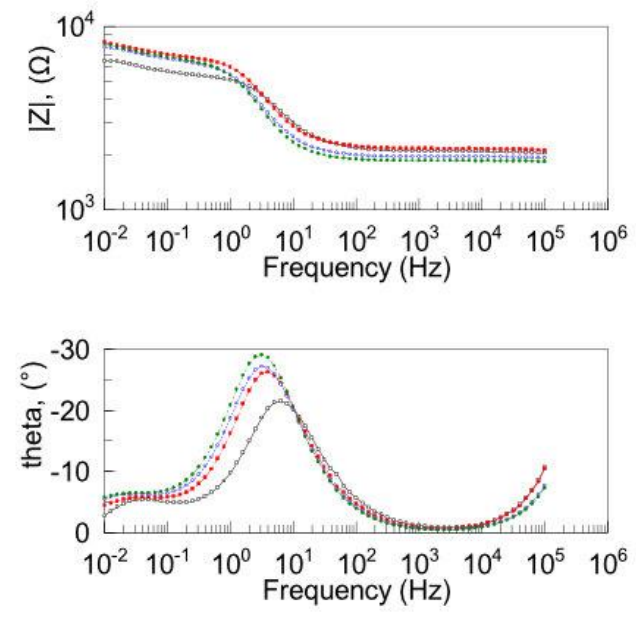

(iv)
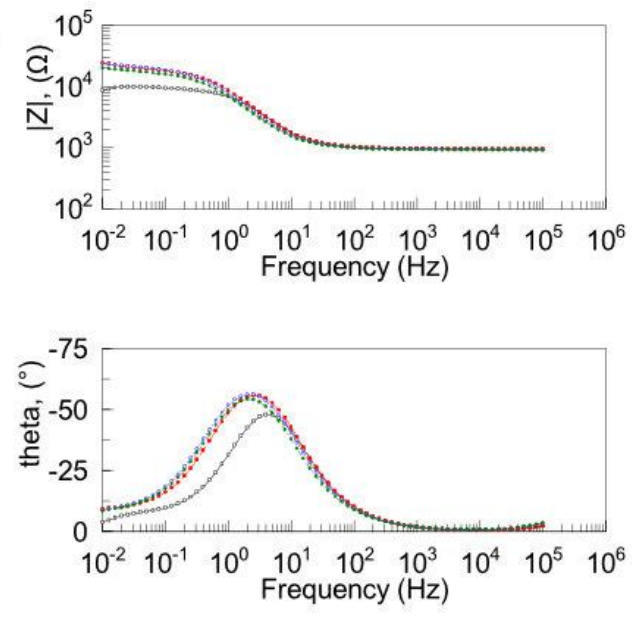

(vi)
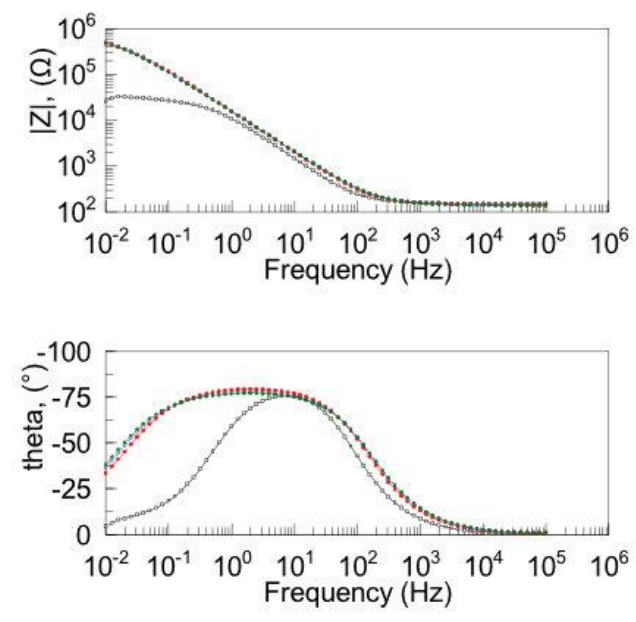
(i)

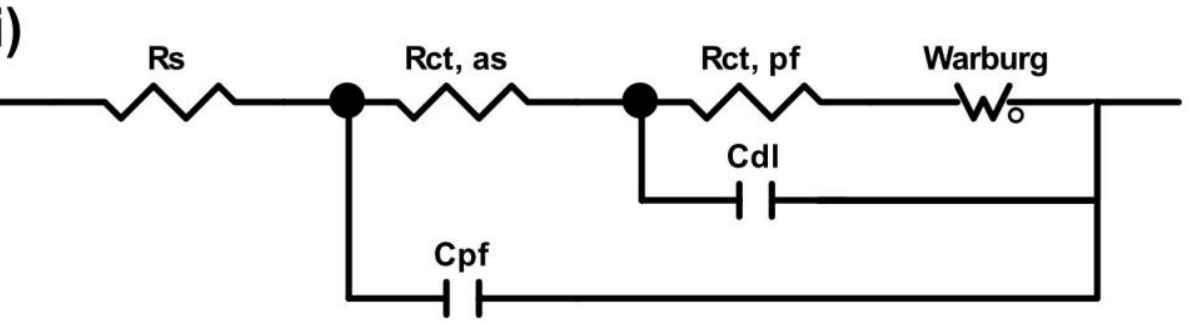

(ii)

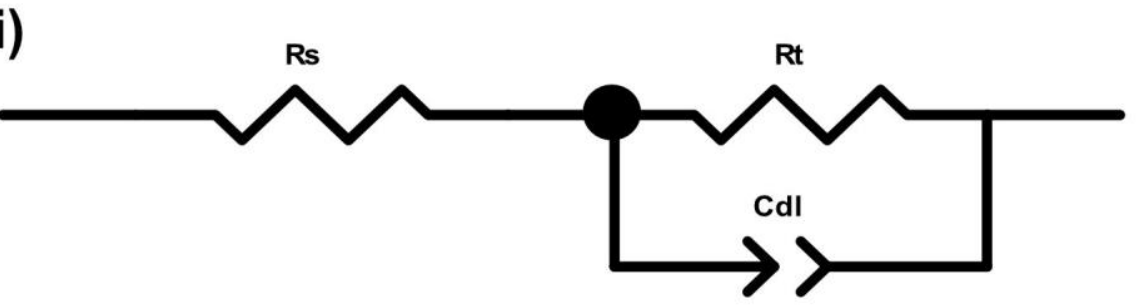

Figure 9 
(i)

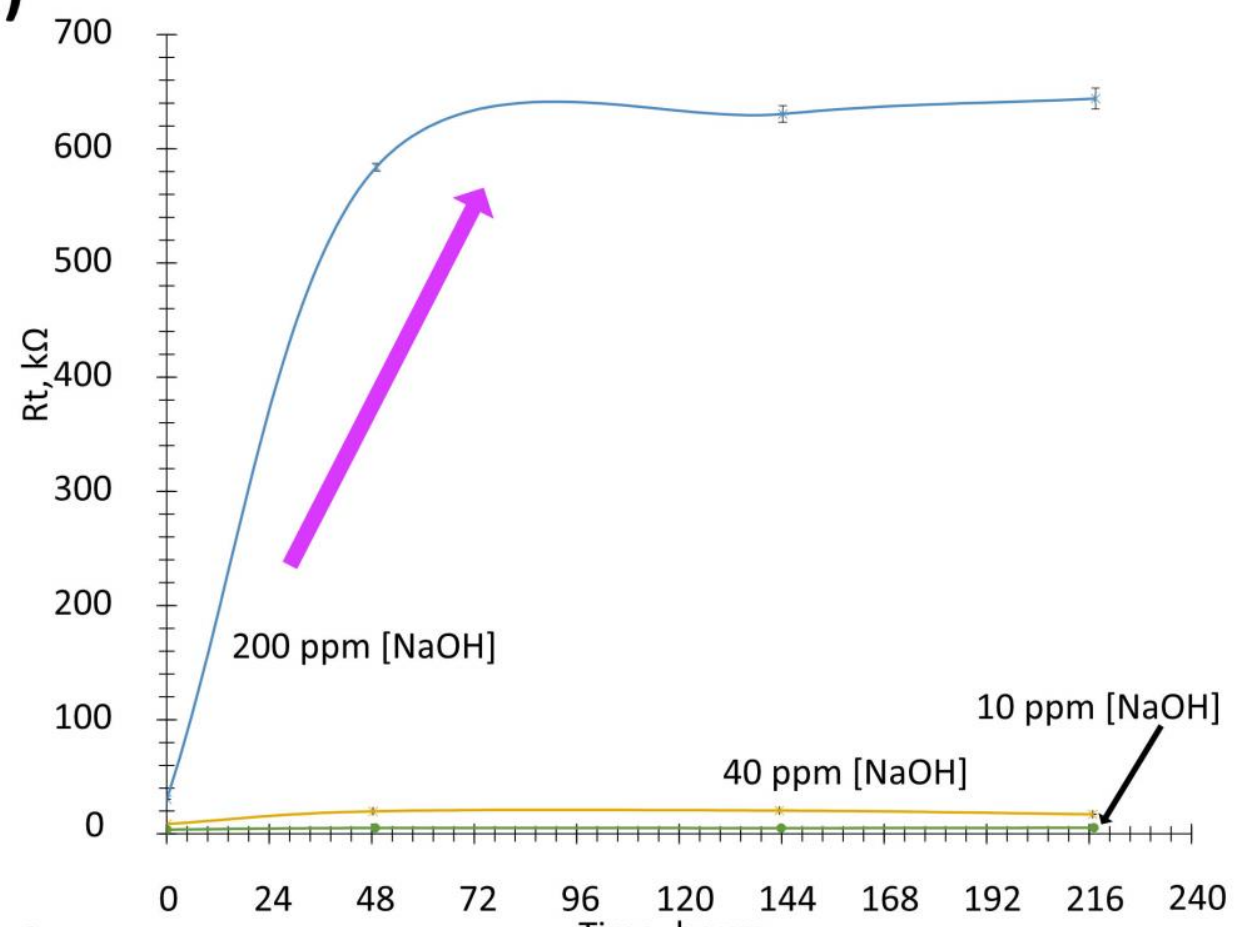

(ii)

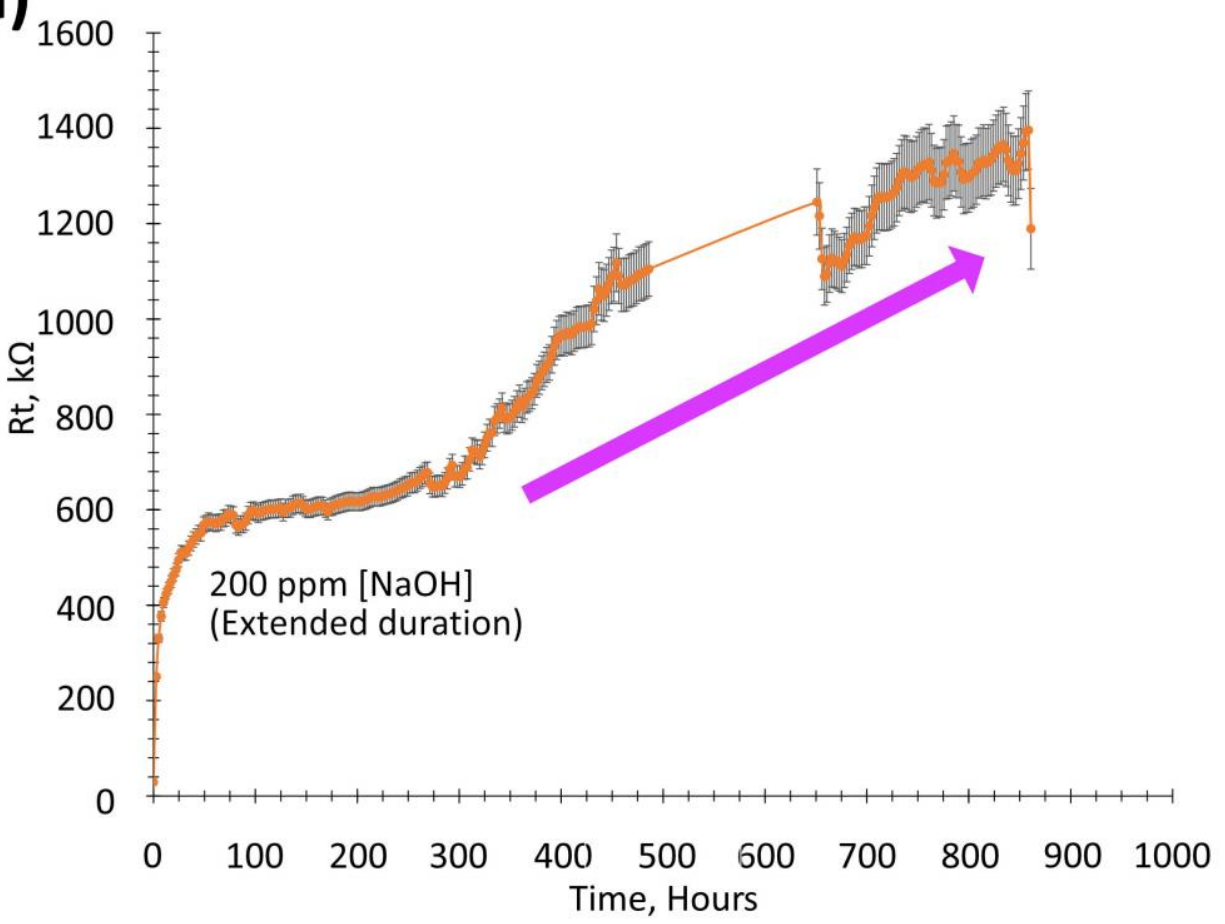

Figure 10 
(i)
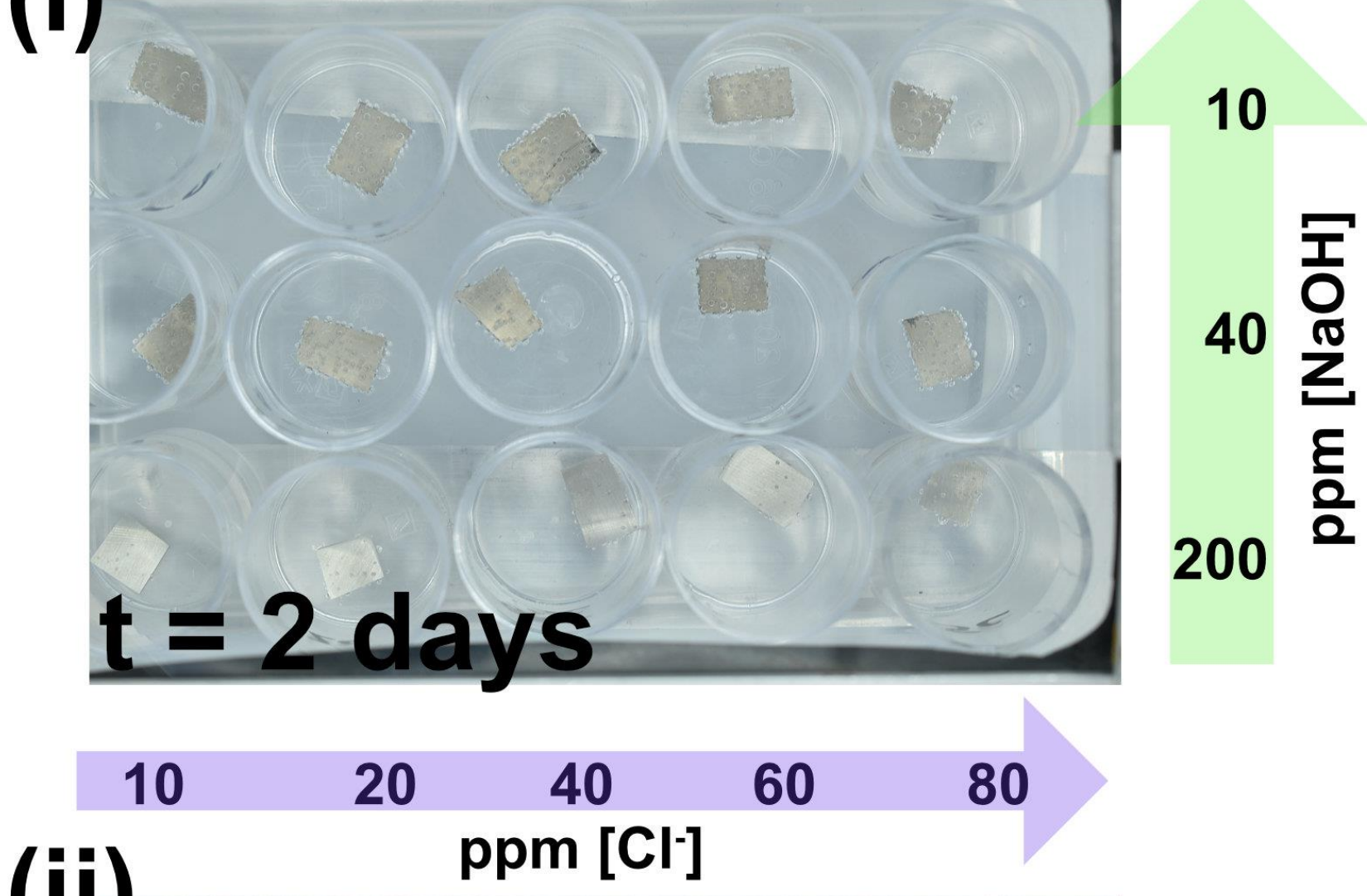

(ii)

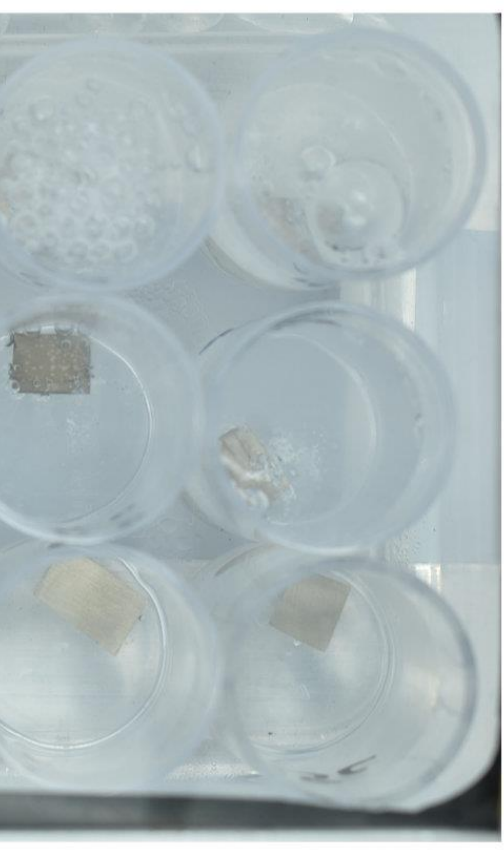

Figure 11 


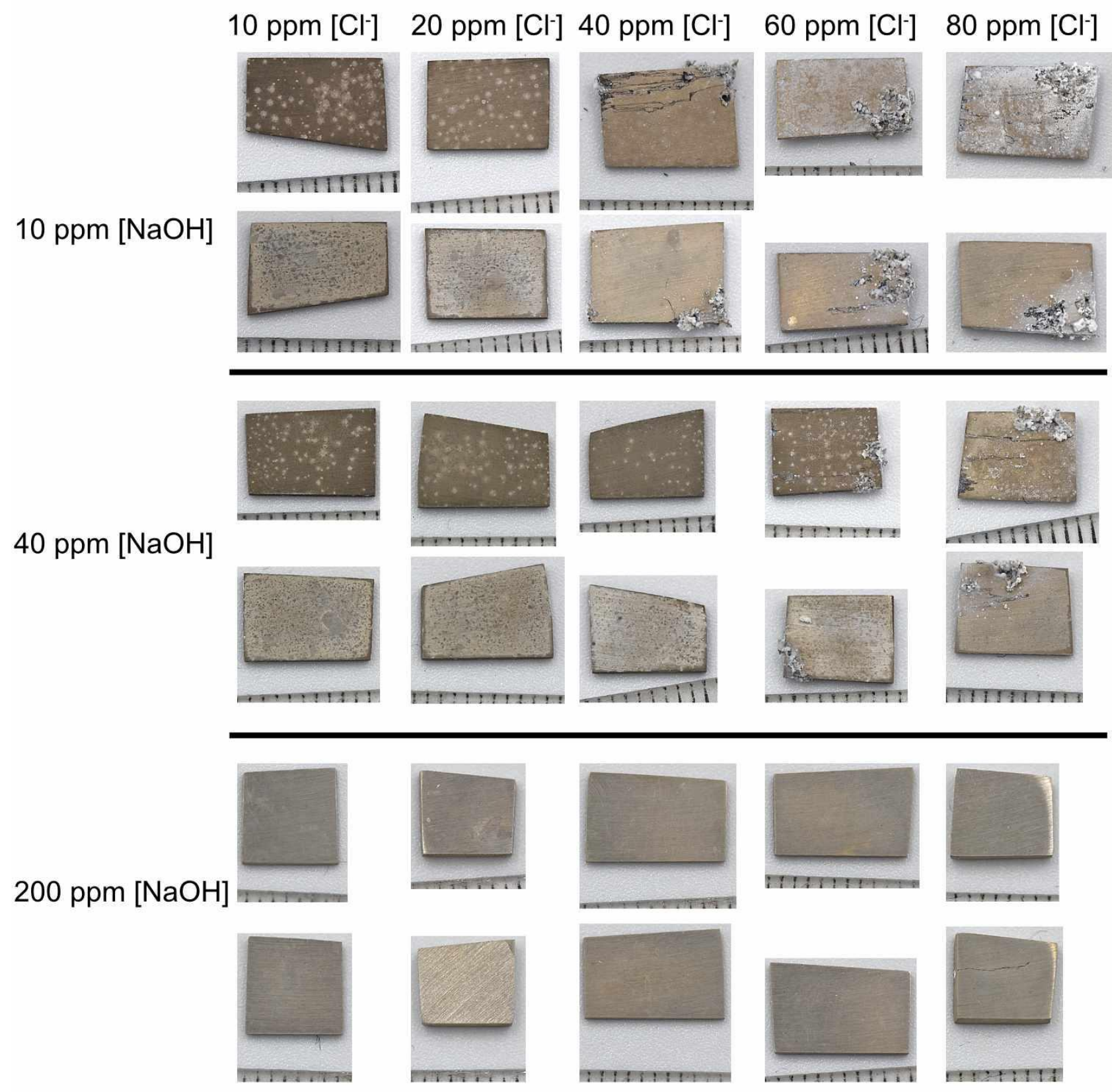

Figure 12 


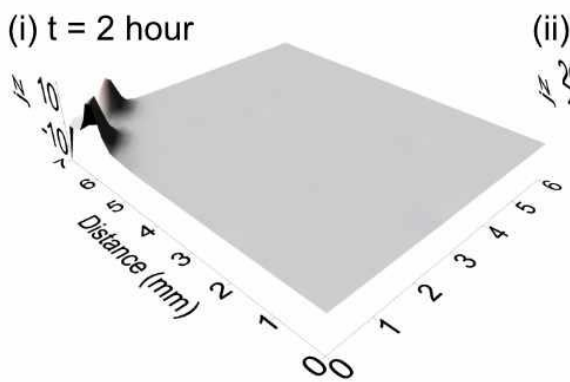

(ii) $\mathrm{t}=4$ hour

(iii) $\mathrm{t}=6$ hour
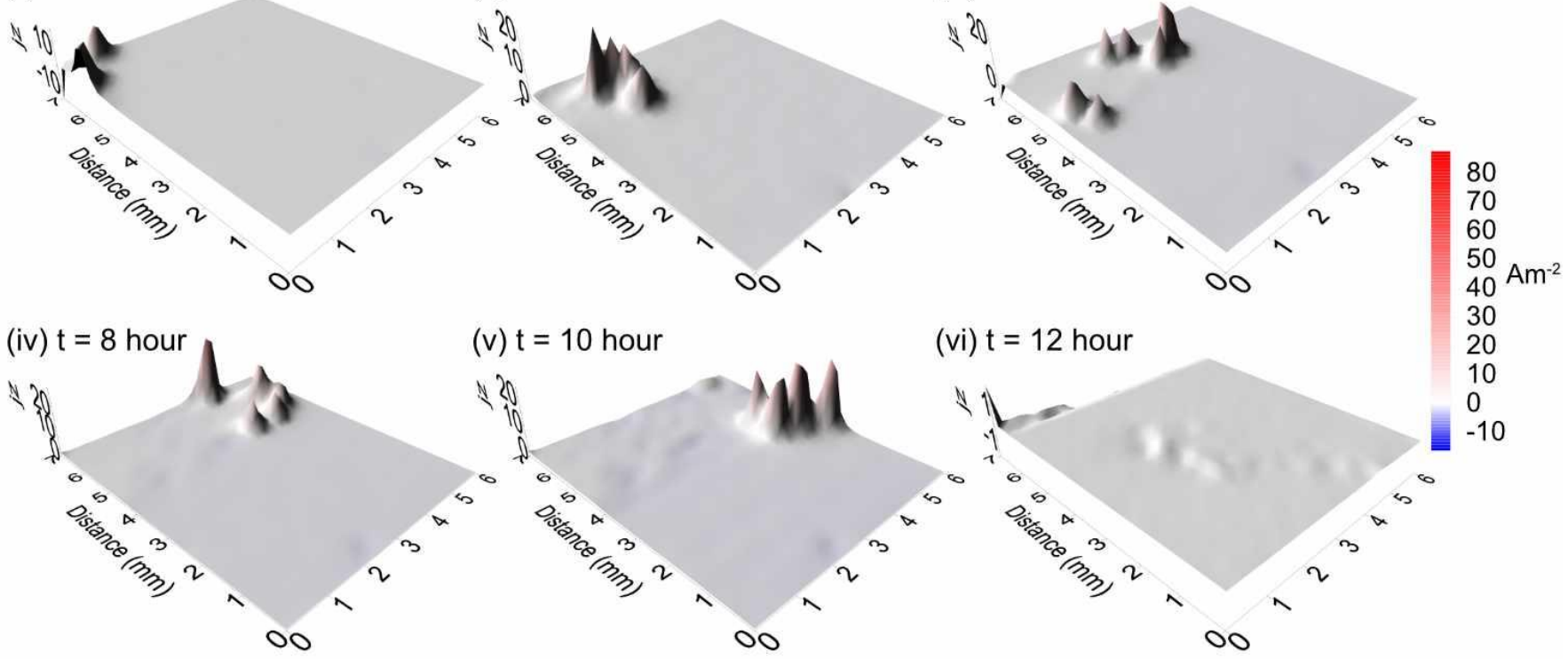

(vi) $\mathrm{t}=12$ hour

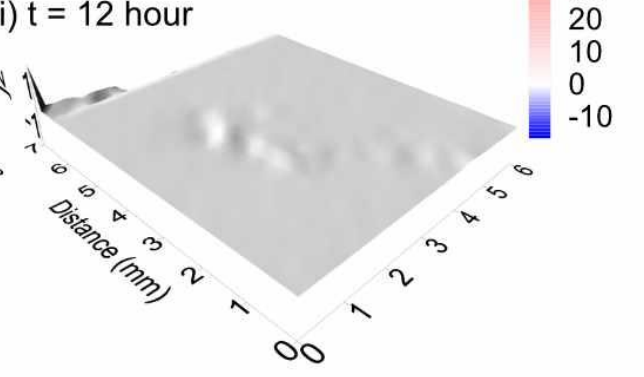

Figure 13 


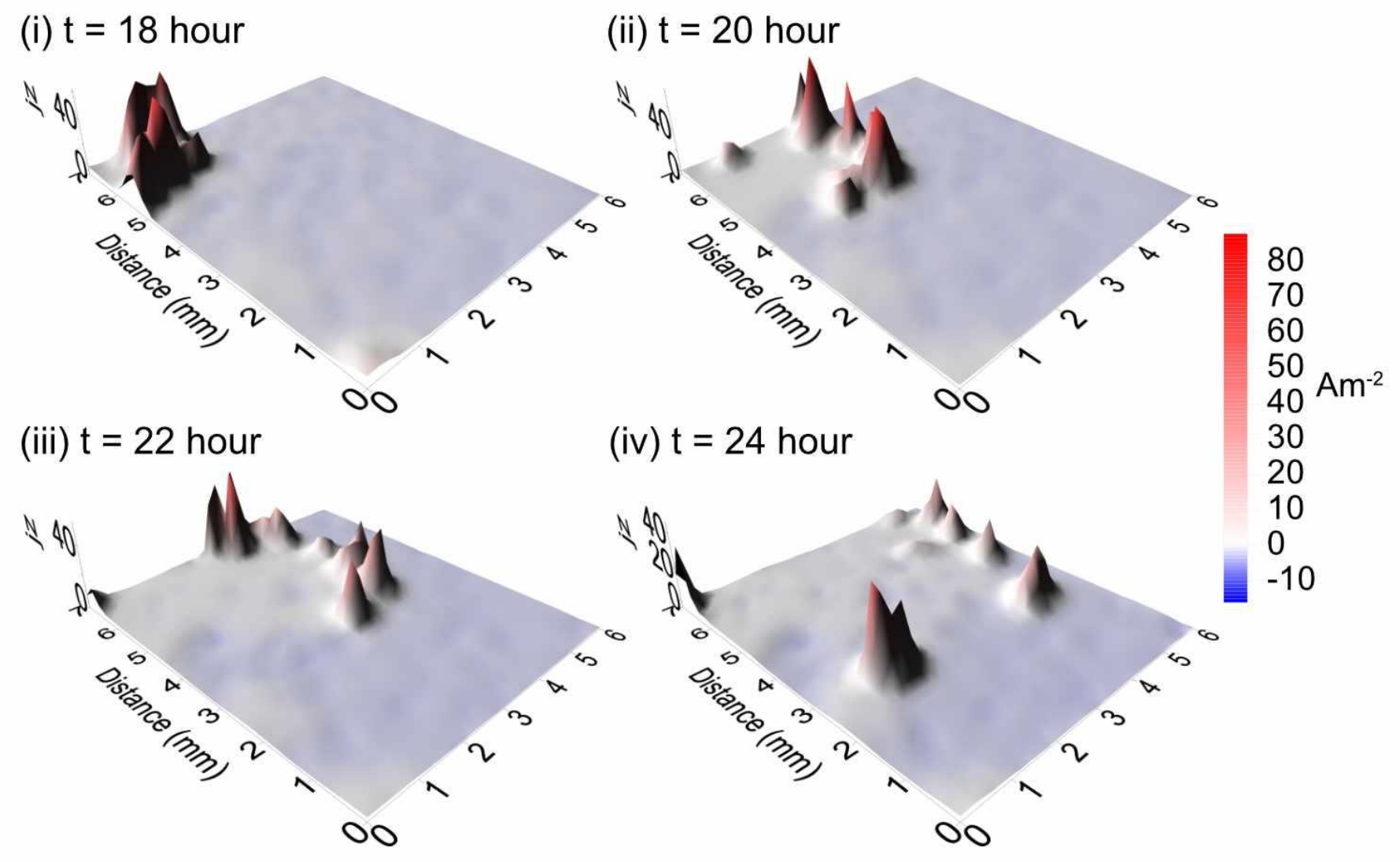

Figure 14 

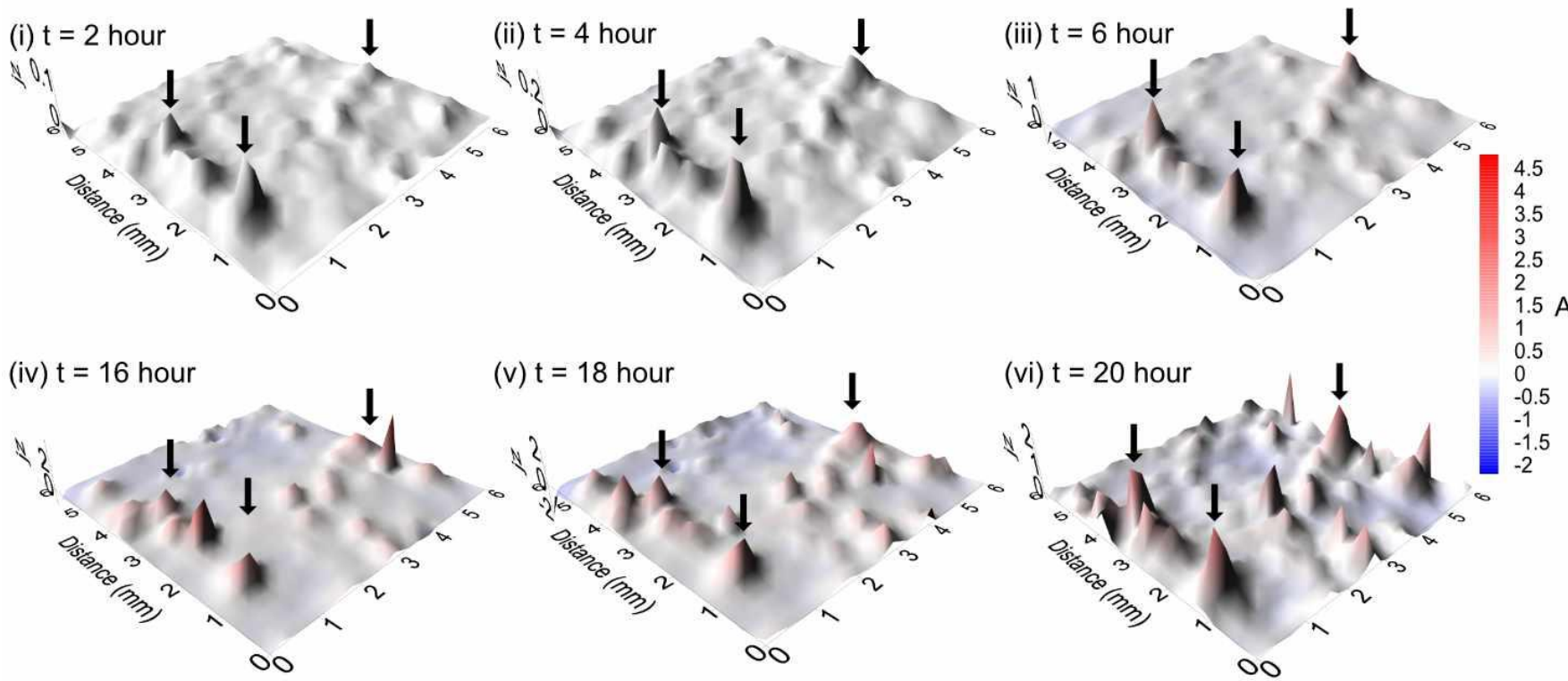

Figure 15 


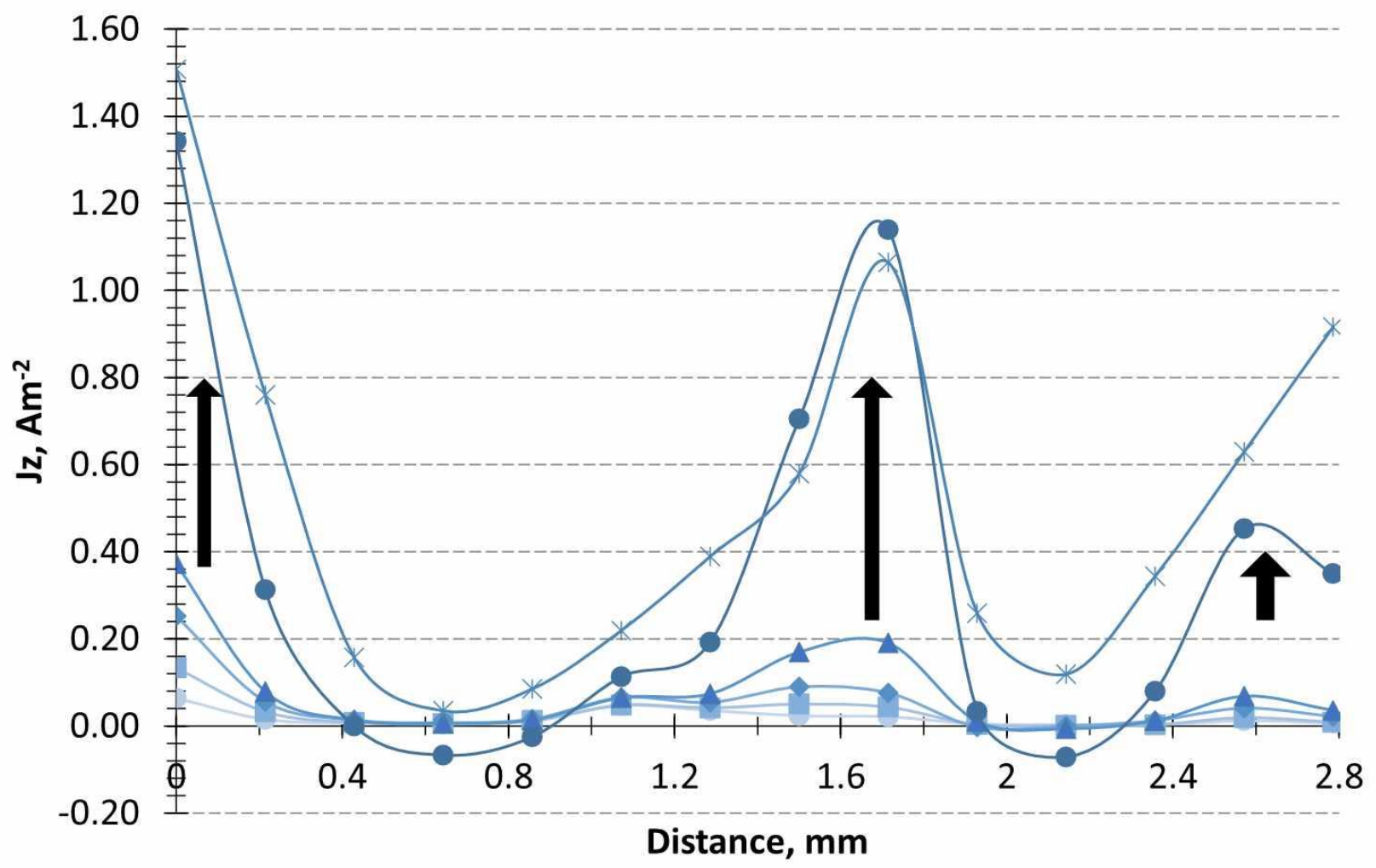

-0 min -60 mins $\rightarrow-120$ mins $₫-180$ mins -10 hours $* 22$ hours

Figure 16 


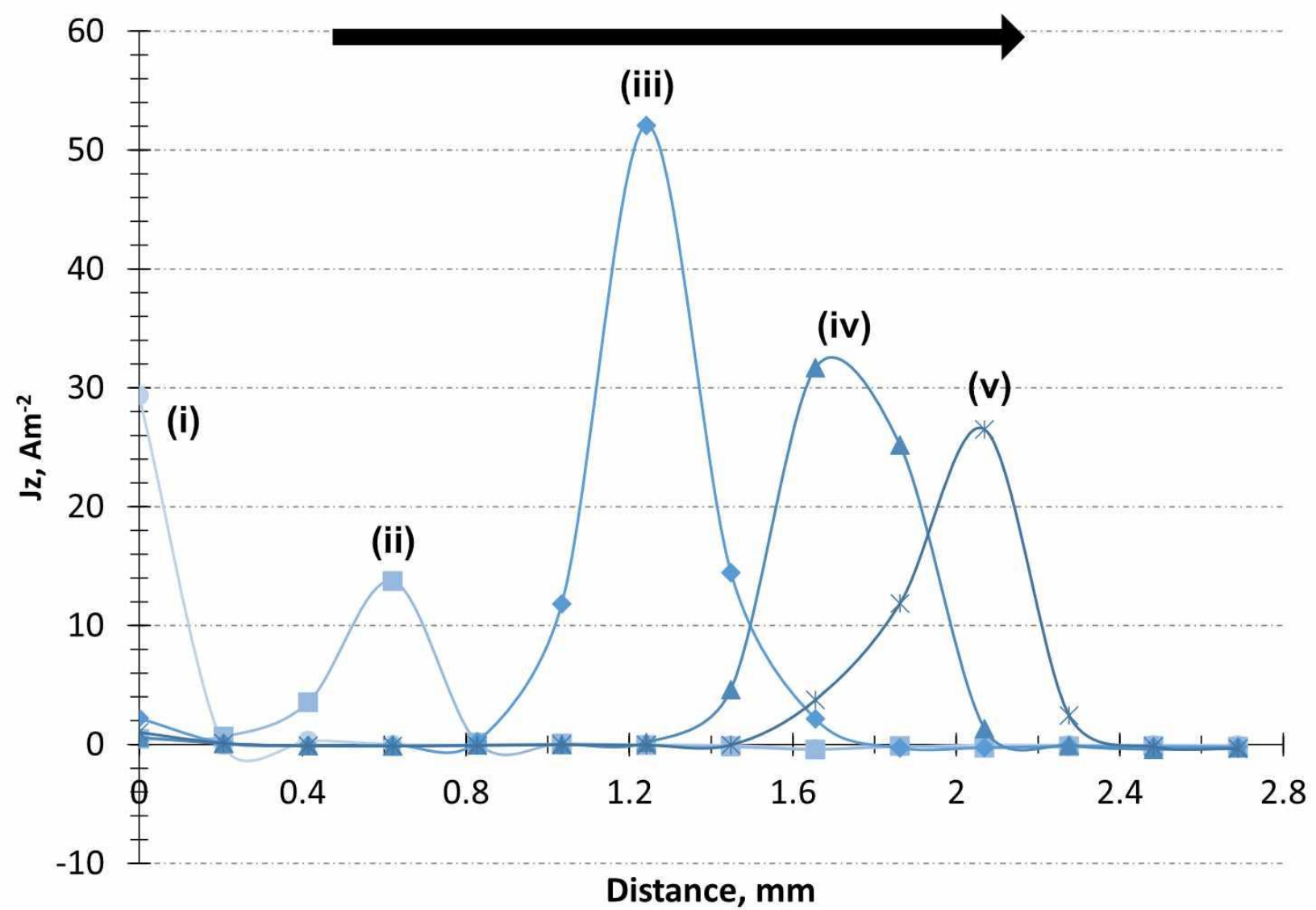

-0 min -60 mins $\rightarrow-80$ mins $₫-115$ mins $* 140$ mins

Figure 17 